\title{
Potential Routes for Thermochemical Biorefineries
}

\begin{abstract}
This critical review focuses on potential routes for the multi-production of chemicals and fuels in the framework of thermochemical biorefineries. The up-to-date research and development in this field has been limited to BTL/G (biomass-to-liquids/gases) studies, where biomass-derived synthesis gas (syngas) is converted into a single product with/without the co-production of electricity and heat. Simultaneously, the interest on biorefineries is growing but mostly refers to the biochemical processing of biomass. However, thermochemical biorefineries (multi-product plants using thermo-chemical processing of biomass) are still the subject of few studies. This scarcity of studies could be attributed to the limitations of current designs of BTL/G for multi-production and the limited number of considered routes for syngas conversion. The use of a platform chemical (an intermediate) brings new opportunities to the design of process concepts, since unlike BTL/G processes they are not restricted to the conversion of syngas in a single-reaction system. Most of the routes presented here are based on old-fashioned and new routes for the processing of coaland natural-gas-derived syngas, but they have been re-thought for the use of biomass and the multiproduction plants (thermochemical biorefinery). The considered platform chemicals are methanol, DME, and ethanol, which are the common products from syngas in BTL/G studies. Important keys are given for the integration of reviewed routes into the design of thermochemical biorefineries, in particular for the selection of the mix of co-products, as well as for the sustainability (co-feeding, $\mathrm{CO} 2$ capture, and negative emissions).
\end{abstract}

Keywords: thermochemical biorefinery; methanol; DME; ethanol; butanol; acetic anhydride

\section{Introduction}

Currently, the uses of biomass as a renewable source account for the production of $1^{\text {st }}$ generation ethanol and FAME (fatty acid methyl ester) biodiesel, in addition to the generation of heat and power. Nonetheless, there is controversy over the use of food-competitive biomass for the production of fuels. The low mass yield of $1^{\text {st }}$ generation processes often makes them unprofitable at current biomass price. Furthermore, expected future regulation of biofuels in the EU could exclude them or impose strong limitations in order to fulfill the sustainability criterion [1]. In response to that, $2^{\text {nd }}$ generation processes have been proposed and several demonstration projects, based on the biochemical conversion of lignocellulosic biomass, are reported for the production of non-food-competitive bioethanol [2,3]. In a prior stage of development are the BTL/G (biomass to liquids/gases) processes, focusing on the thermochemical conversion of biomass into synthesis gas (syngas) or pyrolysis oil, which is then converted into products. 


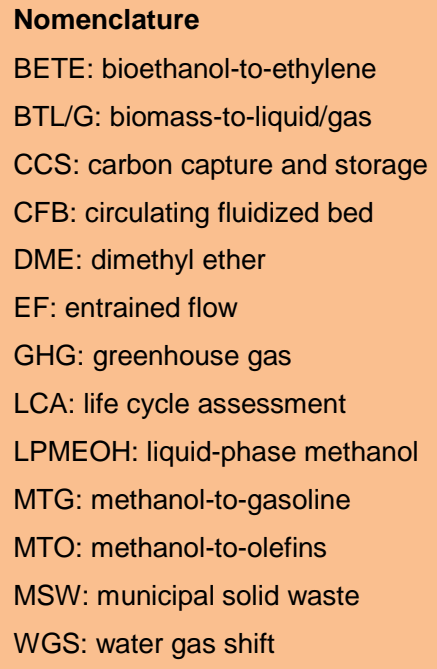

Research on BTL/G processes is limited to various types of potential bio-products [4-8], i.e. Fischer-Tropsch (FT) diesel [9-16], ethanol [17-24], methanol [14,15,25-31], DME [16,29,30,32$36], H_{2}[25,26,30,37,38]$, synthetic natural gas (SNG) $[11,39-43]$ and urea $[14,15]$. Each of these processes has focused on the production of a single fuel, either with or without the coproduction of heat/electricity. Rather than producing a single product, a more interesting option is a multi-product plant, either by combining two or more known BTL/G processes, or based on a chemical intermediate (platform chemical) $[14,44]$.

In a thermochemical biorefinery fuels, chemicals and power are co-produced. A first technoeconomic assessment of such a multi-product plant (thermochemical biorefinery) based on a platform chemical has shown there are important benefits compared to studied BLT/G plants, i.e. greater profitability due to the co-production of high value products, the possibility of overcoming (e.g. in ethanol synthesis) the limitations of product selectivity and a better energy and material integration [44].

Within $2^{\text {nd }}$ generation processes, different concepts of biorefineries are subject of special attention nowadays. Despite the uncertain classification of biorefineries ${ }^{*}$, a thermochemical biorefinery involves (in the opinion of the authors) the processing of biomass and carbon-based waste, i.e. organic fraction of municipal solid waste (MSW), to generate (simultaneously) products and services covering fuels, chemicals, heat and electricity from syngas.

\footnotetext{
* Classification of biorefineries is still under discussion, particularly for the case of thermochemical processing of biomass. The Bioenergy Task 42 (International Energy Agency) has as its objective the classification of biorefinery systems and has proposed a classification method based on four features (i.e. platforms, products, feedstocks and processes) [45]. Although this classification method is useful, e.g. for $C_{5} / C_{6}$ sugars and lignin platform systems, it may not be best option in order to make a thorough classification of biorefineries using syngas as a platform [46].
} 
The production of fuels, chemicals and services from syngas presents little or none differences if coal or natural gas were used as feedstock. However, the benefits of the use of biomass instead of such fossil fuels are well-known. Biomass has a better GHG (greenhouse gas) balance (could even be negative regarding the process), it enhances the security of the energy supply (in case biomass is produced in the same region) and it is the only renewable source for carbon based fuels and chemicals (essential for the production of for example fibers, plastics or jet fuel). For instance, the use of biomass via thermochemical processing is related to the former carbochemistry and the production of chemicals via reforming of natural gas. The fact of being close to current petrochemical facilities should be considered as an advantage, since both the technology and the know-how from the processing of fossil fuels can be adapted and integrated in BTL/G plants and thermochemical biorefineries. Of course, the use of petrochemical technologies involves that BTL/G plants and thermochemical biorefineries should be large enough to achieve the benefits of the economy of scale as in petrochemical facilities.

Contrary to current BTL/G processes, in a thermochemical biorefinery multi-production is the main objective. In a thermochemical biorefinery the existence of a platform chemical brings different options for multi-production. The platform chemical could be a product itself or converted into more products, i.e. following two (or more) different routes resulting in different products. The design of thermochemical biorefineries is of greater complexity than in the case of BTL/G processes. The chemical routes assessed in studied BTL/G processes could be used in the design of thermochemical biorefineries (combining two or more), but as they are not properly suitable for multi-production, the review of other routes (especially for the production of chemicals) is of interest. In this context, several routes were proposed for the production of chemicals and fuels from syngas in the 1980s due to the crude oil crisis, which promoted the search of an alternative feedstock (i.e. natural gas or coal) to substitute crude oil for chemical and fuel production. In some routes, syngas was converted into methanol, which is a platform chemical for the production of for example, gasoline (Methanol-To-Gasoline -MTG-) and olefins (Methanol-To-Olefins -MTO-). Biomass and carbon-based waste are also suitable as crude oil substitutes, since the processing downstream of syngas conditioning is identical. The main advantage of routes via platform chemicals for the design of new concepts of thermochemical biorefineries is their capability to be combined or slightly modified to achieve multi-product generation, as has been already demonstrated [44].

In this review, the most appealing platform chemicals suitable for the design of thermochemical biorefineries have been identified, namely: methanol, DME and ethanol. In section 2, compiled routes via platform chemicals are described and revised in detail, while the well reported MTG and MTO routes are only briefly reviewed. Implications of the use of biomass and carbon-based waste are also detailed together with one example of thermochemical biorefineries based on DME as the platform chemical. 


\subsection{General aspects of thermochemical processing}

Selection of the thermal treatment of biomass depends on further use of the product. For BTL/G processes the thermochemical processing of biomass usually involves gasification or pyrolysis [47-50]. This review will focus only on synthesis routes via gasification.

\subsubsection{Gasification, gas cleaning and conditioning}

Gasification of all carbon-based feedstocks (biomass, coal, carbon-based waste) undergoes the same basic chemistry and thermodynamics [51]. The gasification process can take place at temperatures in the range of $800^{\circ} \mathrm{C}$ to $1800^{\circ} \mathrm{C}$, but in the case of biomass gasification, temperatures are always below $1300^{\circ} \mathrm{C}$ due to softening and melting temperatures of the biomass ashes [51]. Currently, entrained flow bed (EF) and circulating fluidized bed (CFB) operated with oxygen and steam, and indirect circulating fluidized bed (i-CFB) operated with air are the proposed gasification technologies for syngas production from lignocellulosic biomass $[13,14,20,26,39,52]$. Gasification of carbon-based waste is also feasible but the variability of its chemical composition makes it technologically more difficult [51]. Raw syngas from the gasifier needs different cleaning and conditioning treatments, which depend on the further processing of syngas.

\section{Routes via platform chemicals}

The chemistry of these routes is always characterized by the presence of at least one chemical intermediate (platform chemical) generated from syngas. The platform chemical can be directly converted into products or converted into a new chemical intermediate. Most routes were initially proposed in the 1980 s as consequence of the crude oil crisis, since they allow replacing crude oil with coal and natural gas with the production of commodities and fuels. The recovery of crude oil prices led to their abandonment; however, their use has recently been reconsidered for the processing of biomass. Figure 1 shows the routes via platform chemicals which have been reviewed. Most routes are based on the use of methanol or DME, which is easily generated from methanol (dehydration). Ethanol is also included as a platform chemical, although bioethanol is usually not produced from syngas, but directly from biomass. 


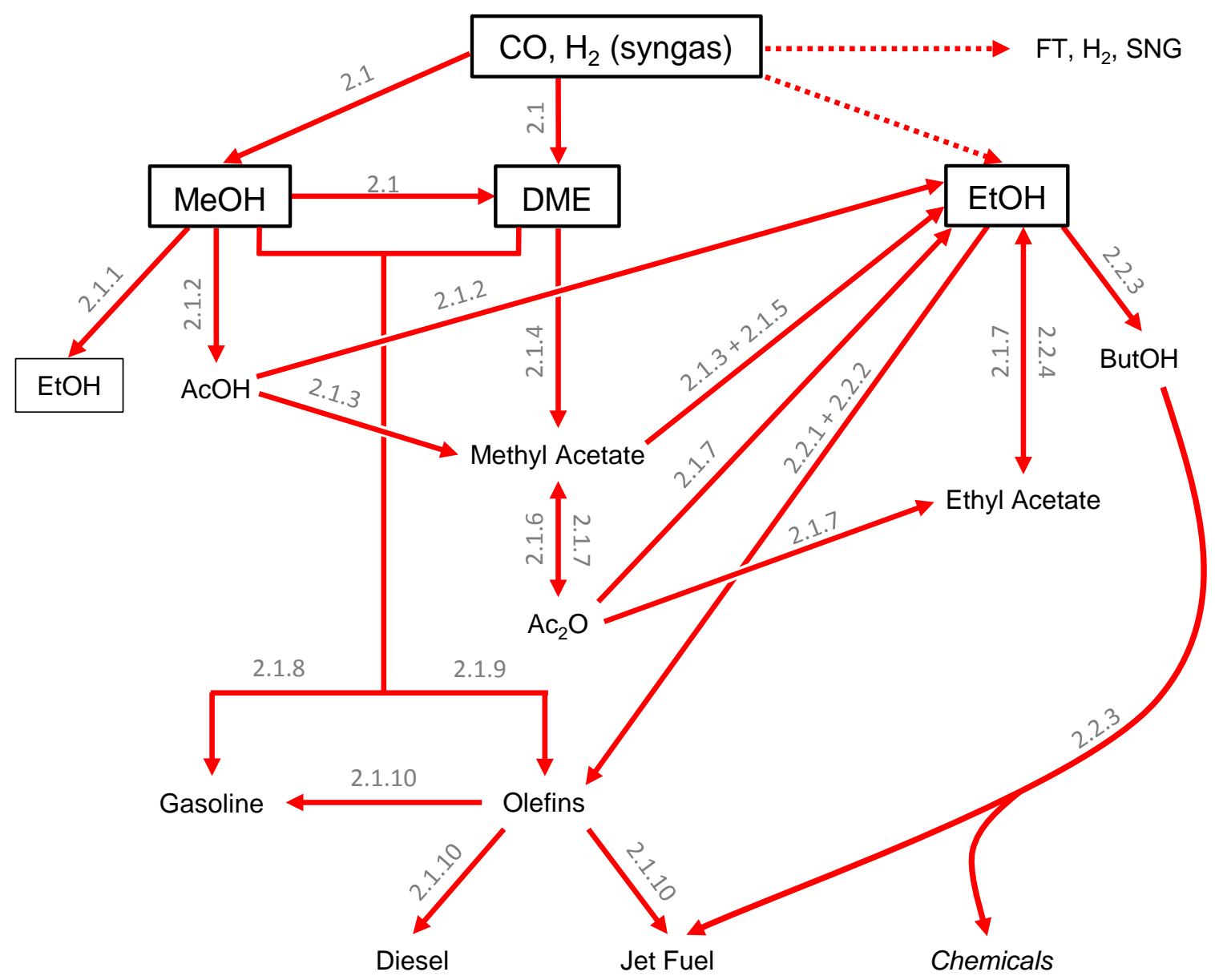

Figure 1. Thermochemical routes via platform chemicals (methanol/DME and ethanol) for the production of chemicals and fuels from syngas.

The chemical equations which are involved in routes via platform chemicals are presented below:

$$
\begin{aligned}
& \mathrm{CO}+2 \mathrm{H}_{2} \rightarrow \mathrm{CH}_{3} \mathrm{OH} \\
& \mathrm{CO}+\mathrm{H}_{2} \mathrm{O} \rightarrow \mathrm{CO}_{2}+\mathrm{H}_{2} \\
& \mathrm{CO}_{2}+3 \mathrm{H}_{2} \rightarrow \mathrm{CH}_{3} \mathrm{OH}+\mathrm{H}_{2} \mathrm{O} \\
& 2 \mathrm{CH}_{3} \mathrm{OH} \rightarrow \mathrm{CH}_{3} \mathrm{OCH}_{3}+\mathrm{H}_{2} \mathrm{O} \\
& 3 \mathrm{CO}+3 \mathrm{H}_{2} \rightarrow \mathrm{CH}_{3} \mathrm{OCH}_{3}+\mathrm{CO}_{2} \\
& \mathrm{CH}_{3} \mathrm{OH}+\mathrm{CO}+2 \mathrm{H}_{2} \rightarrow \mathrm{C}_{2} \mathrm{H}_{5} \mathrm{OH}+\mathrm{H}_{2} \mathrm{O} \\
& \mathrm{CH}_{3} \mathrm{OH}+2 \mathrm{CO}+\mathrm{H}_{2} \rightarrow \mathrm{C}_{2} \mathrm{H}_{5} \mathrm{OH}+\mathrm{CO}_{2} \\
& \mathrm{CH}_{3} \mathrm{OH}+\mathrm{CO} \rightarrow \mathrm{CH}_{3} \mathrm{COOH} \\
& \mathrm{CH}_{3} \mathrm{COOH}+2 \mathrm{H}_{2} \rightarrow \mathrm{C}_{2} \mathrm{H}_{5} \mathrm{OH}+\mathrm{H}_{2} \mathrm{O} \\
& \mathrm{CH}_{3} \mathrm{COOH}+\mathrm{CH}_{3} \mathrm{OH} \rightarrow \mathrm{CH}_{3} \mathrm{COOCH}+\mathrm{H}_{2} \mathrm{O} \\
& \mathrm{CH}_{3} \mathrm{COOH}+\mathrm{C}_{2} \mathrm{H}_{5} \mathrm{OH} \rightarrow \mathrm{CH}_{3} \mathrm{COOCH} \mathrm{CH}_{3}+\mathrm{H}_{2} \mathrm{O} \\
& \mathrm{CH}_{3} \mathrm{COOCH}+2 \mathrm{H}_{2} \rightarrow \mathrm{C}_{2} \mathrm{H}_{5} \mathrm{OH}+\mathrm{CH}_{3} \mathrm{OH} \\
& \mathrm{CH}_{3} \mathrm{COOCH} \mathrm{CH}_{3}+2 \mathrm{H}_{2} \rightarrow 2 \mathrm{C}_{2} \mathrm{H}_{5} \mathrm{OH}^{-} \\
& 2 \mathrm{CH}_{3} \mathrm{OH}+\mathrm{CO}^{\rightarrow} \mathrm{CH}_{3} \mathrm{COOCH}_{3}+\mathrm{H}_{2} \mathrm{O}
\end{aligned}
$$




$$
\begin{aligned}
& \mathrm{CH}_{3} \mathrm{OCH}_{3}+\mathrm{CO} \rightarrow \mathrm{CH}_{3} \mathrm{COOCH}_{3} \\
& \mathrm{CH}_{3} \mathrm{OCH}_{3}+\mathrm{CO}+2 \mathrm{H}_{2} \rightarrow \mathrm{C}_{2} \mathrm{H}_{5} \mathrm{OH}+\mathrm{CH}_{3} \mathrm{OH} \\
& \mathrm{CH}_{3} \mathrm{COOCH}_{3}+\mathrm{CO} \rightarrow\left(\mathrm{CH}_{3} \mathrm{CO}\right)_{2} \mathrm{O} \\
& \left(\mathrm{CH}_{3} \mathrm{CO}\right)_{2} \mathrm{O}+\mathrm{C}_{2} \mathrm{H}_{5} \mathrm{OH} \rightarrow \mathrm{CH}_{3} \mathrm{COOCH}_{2} \mathrm{CH}_{3}+\mathrm{CH}_{3} \mathrm{COOH} \\
& \left(\mathrm{CH}_{3} \mathrm{CO}\right)_{2} \mathrm{O}+\mathrm{CH}_{3} \mathrm{OH} \rightarrow \mathrm{CH}_{3} \mathrm{COOCH}_{3}+\mathrm{CH}_{3} \mathrm{COO} \\
& \mathrm{C}_{2} \mathrm{H}_{5} \mathrm{OH} \rightarrow \mathrm{C}_{2} \mathrm{H}_{4}+\mathrm{H}_{2} \mathrm{O} \\
& 2 \mathrm{C}_{2} \mathrm{H}_{5} \mathrm{OH} \rightarrow \mathrm{C}_{4} \mathrm{H}_{9} \mathrm{OH}+\mathrm{H}_{2} \mathrm{O}
\end{aligned}
$$

\subsection{Methanol/DME as a platform chemical}

The production of methanol from syngas is well documented and represents one of the most important industrial applications of syngas [25-27,53]. Methanol synthesis (Eq. (1)) can be described as a set of two exothermic reversible reactions, namely, conversion of $\mathrm{CO}$ via water gas shift reaction to $\mathrm{CO}_{2}$ (Eq. (2)) and hydrogenation of $\mathrm{CO}_{2}$ to methanol (Eq. (3)) [54]. The catalyst used for methanol synthesis is a $\mathrm{Cu}-\mathrm{ZnO}$ supported on alumina $\left(\mathrm{Al}_{2} \mathrm{O}_{3}\right)$, which has been improved to achieve selectivity to methanol over 99\% [54]. Typical reaction conditions for methanol synthesis are $200-300^{\circ} \mathrm{C}$ and $40-100$ bar [54-55]. Industrial production of methanol is carried out using different reactor configurations. The most important reactors for commercial production of methanol are: tube cool converter, radial flow steam raising converter (R-SRC), axial flow steam raising converter (A-SRC), quench converter (Johnson Matthey Company) [56,57]; combined synthesis converter (Lurgi - Air Liquid Group) [58]; methanol super converter (Mitsubishi Heavy Industries) [56,59]; collect-mix-distribute (CMD) reactor, boiling water reactor (Haldor Topsoe) [56,57]; axial radial concept (ARC) quench type reactor, horizontal steam raising reactor, pseudo isothermal reactor (Methanol Casale) [56,60]; Variobar converter (Linde $A G)$ [55,61]; MRF-Z converter (Toyo Engineering) [61]; and liquid-phase methanol (LPMEOH) reactor (Air Products and Chemicals, Inc.) [56,62].

DME can be produced directly from syngas (Eq. (4)) or indirectly via methanol dehydration (Eq. (5)) $[63,64]$. Typical reaction conditions are $250-400^{\circ} \mathrm{C}$ and up to $20 \mathrm{bar}$, using a dehydration catalyst, e.g. $\gamma$-alumina or zeolites [65,66]. Direct synthesis of DME from syngas is described in [67-69]. Typical reaction conditions are close to methanol synthesis and the catalyst employed is a mixture of methanol synthesis and dehydration catalyst [70]. In the case of methanol dehydration, industrial production of DME is carried out using fixed bed reactors, whereas in the case of direct synthesis similar reactors to those used for methanol synthesis are employed.

\subsubsection{Methanol homologation to ethanol}

The methanol homologation, or methanol reductive carbonylation, route was the first studied route via a platform chemical (1951) to produce ethanol from syngas and remains the most investigated to date. ${ }^{71}$ Methanol homologation was envisioned along with direct conversion of syngas to ethanol as an alternative process to produce ethanol from coal [72]. Despite the great interest in the 1980s the methanol homologation route has been nearly disregarded and neither 
a pilot plant nor commercial process based on this route has been constructed [4]. For a profitable application of the methanol homologation route, development of non-toxic homogeneous catalysts which could be easily (and economically) recovered, or heterogeneous/supported catalysts achieving yields to ethanol similar to those in the case of homogeneous catalysts, are needed.

The methanol homologation route comprises two consecutive steps to make ethanol from syngas: methanol synthesis (Eq. (1)) and methanol homologation (Eq. (6) or Eq. (7)). In a possible process based on this route, syngas would be first converted in a methanol synthesis reactor and the outlet stream would be directly fed to the homologation reactor where unconverted syngas and previously generated methanol react at $150-200^{\circ} \mathrm{C}$ and high pressures (100-300 bar) producing ethanol, and to a lesser extent, oxygenates and hydrocarbons.

The methanol homologation step can be carried out via different kinds of homogeneous catalyst. The first study of methanol homologation was presented by Wender et al. using a Cobased homogeneous catalyst in a batch reactor [71]. Depending on the $\mathrm{H}_{2} / \mathrm{CO}$ molar ratio in the homologation reactor feed, the homologation can occur by Eq. (6) or Eq. (7), resulting in the generation of either water or $\mathrm{CO}_{2}$ as a by-product. Table 1 shows the common chemical states for the studied homologation catalysts along with the main promoters for the reaction. A detailed description of the kinetics and reaction mechanism of the homologation reaction is presented elsewhere [73-77]. The main active complex in the homologation reaction can be described by the formula $\left[\mathrm{M}(\mathrm{CO})_{\mathrm{n}}\right]^{\mathrm{d}}$, where $\mathrm{M}$ represents the active component, $\mathrm{n}$ is the coordination factor (frequently: $3,4,12$ ) and $d$ is always negative (often -1). This complex allows itself the CO insertion in the methanol molecule. However, promoters and additives are required in order to increase the rate of reaction and selectivity, and avoid complex irreversible degradation [78]. Promoters can be present in different chemical species, e.g. $\mathrm{CH}_{3} \mathrm{l}$, phosphine $[79,80]$. Additives, mainly oxygenates compounds, affect product distribution since most are products of the secondary reactions during homologation [81-85]. These additives shift secondary reactions, which are in equilibrium, at operating conditions of methanol homologation. Attempts to use heterogeneous or supported catalysts are reported in the literature but the results obtained are still unsatisfactory $[86,87]$. 
Table 1. Chemical state for the catalyst used in the methanol homologation route.

\begin{tabular}{|c|c|c|c|c|c|c|c|c|c|c|c|}
\hline & & & & & ch & emical & state & & & & \\
\hline & & Acetate & Carbonate & Carbonyl & Formate & Oxide & Carboxylate & Elemental & Chloride & Organic & \\
\hline & & 1 & 4 & 1 & 1 & 1 & 1 & 1 & 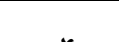 & $x$ & {$[4$} \\
\hline & $60-r \pi 11$ & r & ( & 政 & ( & 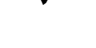 & 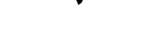 & 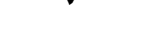 & & & $71,88,89]$ \\
\hline 등 & $\mathrm{Mn}$ & $\checkmark$ & $\checkmark$ & $x$ & $x$ & $\checkmark$ & $x$ & $\checkmark$ & $\checkmark$ & $x$ & {$[72,90]$} \\
\hline ๘ & $\begin{array}{c}\text { Fe-Rh- } \\
\text { Mn }\end{array}$ & $x$ & $x$ & $\checkmark$ & $x$ & $x$ & $x$ & $x$ & $x$ & $x$ & [91-93] \\
\hline & I & $x$ & $x$ & $x$ & $x$ & $x$ & $x$ & $\checkmark$ & $x$ & $\checkmark$ & [94] \\
\hline 苑 & $\mathrm{P}$ & $x$ & $x$ & $x$ & $x$ & $\checkmark$ & $x$ & $\checkmark$ & $x$ & $\checkmark$ & [85] \\
\hline 을 & $\mathrm{Ru}$ & $\checkmark$ & $x$ & $\checkmark$ & $x$ & $\checkmark$ & $x$ & $x$ & $\checkmark$ & $x$ & [94-96] \\
\hline
\end{tabular}

Despite the great number of patents and publications on the methanol homologation route, neither a commercial process, nor even an industrial program has been developed. The only active project, at laboratory scale, is called the Dry Ethanol Process, carried out by the Argonne National Laboratory [93-97]. This process follows Eq. (7), so no water is generated, and uses a Fe-Mn-based homogeneous catalyst with $n$-methylpiperidine as the promoter. The main advantage of this route is the absence of water in products, which makes the recovery of ethanol easier [93].

There is a lack of knowledge on the deactivation of the methanol homologation catalyst. According to Ishogai, it would be possible to use syngas with low contents of methane, ethylene and $\mathrm{CO}_{2}$ without a significant negative impact on the catalyst [85]. Due to the scarcity of information, the experience gained from the most similar process, acetic acid synthesis (Monsanto Process), could be helpful $[54,78]$.

The research on methanol homologation following Eq. (6) is limited at laboratory scale, but there are some patents describing preliminary conceptual designs [81,88]. In a similar way to LPMEOH synthesis, the homogeneous catalyst requires the presence of an inert solvent to carry out the reaction [81]. The solvent, e.g. the same used in $\mathrm{LPMEOH}$, has to ensure liquidliquid equilibrium (water-products/solvent-catalyst-syngas) [83]. Hence, the homologation of methanol should be carried out for example, in a batch reactor, a continuous stirred tank reactor (CSTR), a bubbling column with internal recycle, or another kind of reactor available for homogeneous catalysts. Table 2 shows a collection of reaction data for methanol homologation following Eq. (6). Although general references claim that methanol homologation needs pressures of about 300 bar, which was only true in the first stage of development of the homologation catalyst [98]. The use of promoters allowed a reduction of operating pressure, which is limited by the condition of retaining methanol as liquid in the reactor (usually limited to a total pressure of 50 bar). Detailed information on product selectivity for a catalyst with Ru can be found in Jenner [99]. Through the use of additives, ethanol selectivity is improved up to 91-93\% [89]. 
Table 2. Reaction conditions, product distribution and main additives for homologation catalysts.

\begin{tabular}{|c|c|c|c|c|c|c|c|c|c|c|c|c|c|c|c|}
\hline \multirow[b]{2}{*}{ Catalyst } & \multicolumn{6}{|c|}{ reaction conditions $^{a}$} & \multicolumn{8}{|c|}{ product yield (\%) } & \multirow{2}{*}{$\begin{array}{c}\text { additives }^{\mathbf{b}} \\
{[81,84]}\end{array}$} \\
\hline & $\mathrm{T}\left({ }^{\circ} \mathrm{C}\right)$ & $\begin{array}{c}\mathrm{P} \\
\text { (bar) }\end{array}$ & $\begin{array}{l}\text { Residence time } \\
\text { (min) }\end{array}$ & $\begin{array}{c}\mathrm{H}_{2} / \mathrm{CO} \text { molar } \\
\text { ratio }\end{array}$ & $X_{c o}$ & $\mathrm{X}_{\text {Methanol }}$ & Ethanol & Propanol & $\begin{array}{c}\text { Ethyl } \\
\text { acetate }\end{array}$ & $\begin{array}{l}\text { Oxygenates } \\
\text { c }\end{array}$ & $\mathrm{CO}_{2}$ & $\mathrm{CH}_{4}$ & Others & Water & \\
\hline$\left[\mathrm{Co}(\mathrm{CO})_{4}\right]_{2}[71]$ & $\begin{array}{l}180- \\
185\end{array}$ & 205 & 480 & 1 & $\mathrm{~N} / \mathrm{A}$ & $76.4 \%$ & 38.8 & 4.7 & 6.3 & 12.0 & $\mathrm{~N} / \mathrm{A}$ & 8.5 & 6.1 & 90.8 & acetone \\
\hline Co-I catalyst [88] & 190 & 100 & 300 & 2 & $\mathrm{~N} / \mathrm{A}$ & $70 \%$ & 52.71 & $11.55^{\mathrm{d}}$ & 3.71 & $2.03^{\mathrm{e}}$ & $\mathrm{N} / \mathrm{A}$ & 0 & 0 & $\mathrm{~N} / \mathrm{A}$ & n-propanol \\
\hline Rh/(Ru-I-P) [100] & 140 & 83 & 180 & 3 & $\mathrm{~N} / \mathrm{A}$ & NA & $89^{\dagger}$ & NA & NA & NA & $\mathrm{N} / \mathrm{A}$ & $\mathrm{N} / \mathrm{A}$ & $\mathrm{N} / \mathrm{A}$ & $\mathrm{N} / \mathrm{A}$ & n-outanol \\
\hline $\mathrm{Co}(\mathrm{OAc})_{2} \cdot 4 \cdot \mathrm{H}_{2} \mathrm{O}[81]$ & 185 & 200 & 120 & 2 & $\mathrm{~N} / \mathrm{A}$ & $35.1 \%$ & 25.5 & NA & NA & NA & $\mathrm{N} / \mathrm{A}$ & $\mathrm{N} / \mathrm{A}$ & N/A & N/A & acetate \\
\hline $\begin{array}{c}\mathrm{Co}(\mathrm{OAc})_{2} \cdot 4 \cdot \mathrm{H}_{2} \mathrm{O}-\mathrm{I}-\mathrm{P} \\
{[83]}\end{array}$ & 205 & 200 & 120 & 1 & $\mathrm{~N} / \mathrm{A}$ & $47.0 \%$ & 32.8 & NA & NA & $\sim 8$ & $\mathrm{~N} / \mathrm{A}$ & $\mathrm{N} / \mathrm{A}$ & $\sim 6$ & N/A & benzoic acid \\
\hline
\end{tabular}

a All collected data refers to batch reactors.

${ }^{\mathrm{b}}$ Refers to all catalysts.

${ }^{c}$ Other oxygenates.

${ }^{\mathrm{d}}$ Propanol, propanal and methyl acetate.

${ }^{\text {e }}$ Acetic acid.

${ }^{\dagger}$ Selectivity to ethanol and acetic acid.

$\mathrm{N} / \mathrm{A}=$ not available.

Table 3. Reaction conditions for the Dry Ethanol Process

\begin{tabular}{|c|c|c|c|c|c|c|c|c|c|c|c|c|c|c|}
\hline \multirow{2}{*}{ Catalyst } & \multicolumn{6}{|c|}{ reaction conditions $^{a}$} & \multicolumn{8}{|c|}{ product yield (\%) } \\
\hline & $\mathrm{T}\left({ }^{\circ} \mathrm{C}\right)$ & $\mathrm{P}$ (bar) & Residence time (min) & $\mathrm{H}_{2} / \mathrm{CO}$ molar ratio & $\mathrm{X}_{\mathrm{CO}}$ & $X_{\text {Methanol }}$ & Ethanol & Propanol & Ethyl acetate & Oxygenates $^{b}$ & $\mathrm{CO}_{2}$ & $\mathrm{CH}_{4}$ & 4 Others & Water \\
\hline Fe-Rh-Mn [93-97] & $180-220$ & 300 & 360 & $1 / 3$ & $\mathrm{~N} / \mathrm{A}$ & $\mathrm{N} / \mathrm{A}$ & N/A & N/A & $\mathrm{N} / \mathrm{A}$ & $\mathrm{N} / \mathrm{A}$ & $\mathrm{N} / \mathrm{A}$ & $\mathrm{N} / \mathrm{A}$ & $\mathrm{N} / \mathrm{A}$ & $\mathrm{N} / \mathrm{A}$ \\
\hline
\end{tabular}




\subsubsection{Methanol to ethanol via acetic acid hydrogenation}

The acetic hydrogenation route comprises a set of common steps: methanol synthesis (Eq. (1)), acetic acid synthesis (Eq. (8)) and acetic acid hydrogenation (Eq. (9)). As shown in Figure 2, syngas is used for methanol synthesis, as commented in section 2.1., and also to provide CO for the synthesis of acetic acid. Produced methanol is carbonylated using a homogeneous catalyst. Acetic acid is then directly hydrogenated to ethanol and water. Regarding the conditions of the acetic acid hydrogenation, i.e. considered catalyst and reaction conditions, more steps could be needed for subproduct conversion by recycling or chemical conversion in additional reactors [101].

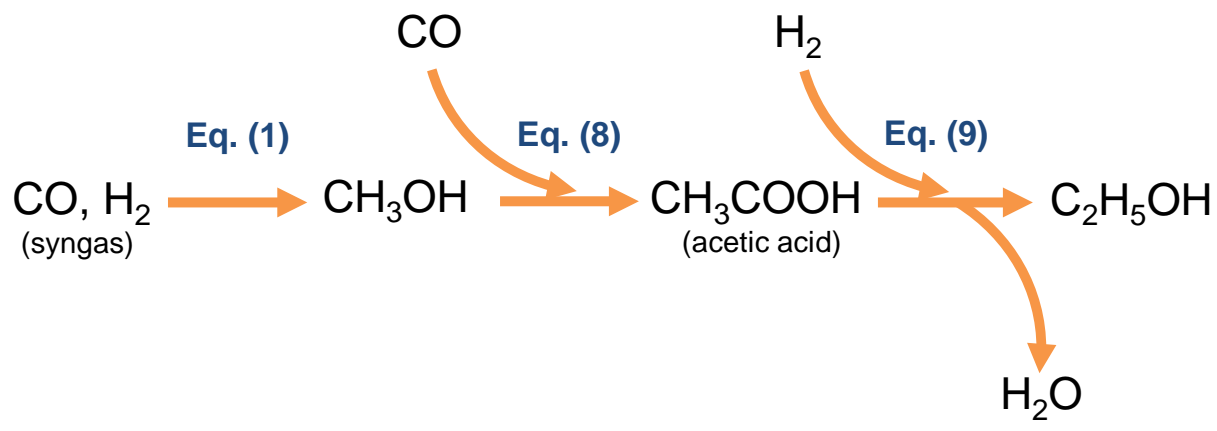

Figure 2. Chemical scheme for the acetic acid hydrogenation to ethanol.

The acetic acid hydrogenation route was developed in the early 1980s [4]. This route is based on the hydrogenation of acetic acid to yield ethanol, and to a lesser extent, acetates using heterogeneous catalysts. The employment of a heterogeneous catalyst is the main advantage of this route compared with the methanol homologation route. As in the case of methanol homologation, the end of the crude oil crisis was the main reason for its withdrawal, but in the case of the acetic acid hydrogenation route, the corrosiveness of the reaction mixture (with a detrimental effect on the life of hydrogenation catalyst) was also determinant [101-103].

The synthesis of acetic acid is one of the most important examples of industrial processes using homogeneous catalysts. When the hydrogenation of the acetic acid route was in the first stage of development, conventional synthesis of acetic acid was mainly conducted via the Monsanto process operating at $150-200{ }^{\circ} \mathrm{C}$ and $30-60$ bar with very high selectivity to acetic acid [104]. The Monsanto process uses a Rh-based homogeneous catalyst, which is converted in-situ into an active Rh-carbonyl catalyst as described in 2.1.1. for methanol homologation [104]. Currently, BP's Cativa process has emerged as the best available technology for acetic acid production [105]. The Cativa process is similar to Monsanto's except for the catalyst. In the Cativa process an Ir-based catalyst is used, featuring a higher catalyst lifetime and better stability and recovery $[105,106]$.

The hydrogenation of acetic acid is carried out at liquid phase (and high $\mathrm{H}_{2}$ pressure) using a conventional catalyst for organic compound hydrogenation $[107,108]$. Typical reaction 
conditions for the ENSOL process are $230-270^{\circ} \mathrm{C}$ and $40-120$ bar [108]. A detailed description of kinetics and reaction mechanisms along with catalyst behavior can be found elsewhere [103,109-111]. Catalysts considered in the literature for acetic acid hydrogenation to ethanol are $\mathrm{Co}, \mathrm{Cu}, \mathrm{Fe}$-based dispersed on silica support [112], supported Pt-based [103,109,110] and Pdbased catalyst $[111,113]$. These studies differ from the ENSOL process in operating conditions. Whereas the BASF process achieves near complete conversion of acetic acid at moderately high pressures (40-120 bar) [108], the other studies always operated at near atmospheric pressure and achieve very low per pass conversion of acetic acid (around 5\%) with high lights formation [107,112]. According to the reaction mechanism, acetaldehyde is the main intermediate of the reaction and sometimes the reaction could not proceed further depending on catalyst and operating conditions (partial pressure of $\mathrm{H}_{2}$ ) [111]. Therefore, acetic acid conversion to acetaldehyde is the subject of more studies in the literature than to ethanol. The reaction is quite selective to ethanol, ethyl acetate and n-butanol being the only by-products in the aqueous phase, and with low gas formation ( $\mathrm{CO}$ and methane) [108]. Both liquid byproducts can be partially converted into ethanol by recycling them into the reactor [108]. The reaction mixture (aqueous phase) is highly corrosive, which leads to rapid catalyst degradation, and becomes the main limitation for the reaction. Although reaction in the vapor phase could avoid catalyst degradation by reducing the corrosiveness of the reaction mixture, extremely high partial pressures of $\mathrm{H}_{2}$ (of at least 270 bar) would be needed [108]. Recent efforts to produce new catalysts for the hydrogenation of acetic acid have been conducted by Range Fuels Inc. and Celanese International Corp [114,115]. Celanese has developed a Pt-Sn catalyst (see Table 4) that allows higher productivity for acid acetic hydrogenation to an ethanol/ethyl acetate mixture with remarkably high space velocity and global selectivity (to both ethanol and ethyl acetate) [115]. Other recent improvements in hydrogenation catalysts, i.e. nano Pd-based catalyst, have been carried out by BASF [116].

Table 4. Reaction conditions and product distribution for acetic acid hydrogenation catalysts.

\begin{tabular}{|c|c|c|c|c|c|c|c|c|c|c|c|}
\hline \multirow[b]{2}{*}{ catalyst } & \multicolumn{5}{|c|}{ reaction conditions $^{a}$} & \multicolumn{6}{|c|}{ product yield (\%) } \\
\hline & $\begin{array}{c}\mathrm{T} \\
\left({ }^{\circ} \mathrm{C}\right)\end{array}$ & $\begin{array}{c}\mathrm{P} \\
\text { (bar) }\end{array}$ & $\begin{array}{l}\text { GSHV } \\
\left(\mathrm{h}^{-1}\right)\end{array}$ & $\begin{array}{c}\mathrm{H}_{2} \text { /acetic } \\
\text { acid }\end{array}$ & Conversion & Ethanol & $\begin{array}{c}\text { Ethyl } \\
\text { acetate }\end{array}$ & $\begin{array}{c}\text { Oxygenates } \\
\text { b }\end{array}$ & $\mathrm{CO}_{2}$ & $\mathrm{CH}_{4}$ & Others \\
\hline $\begin{array}{c}\text { Co-Cu- } \\
\text { Mn-Mo } \\
{[108]}\end{array}$ & $\begin{array}{l}230- \\
270\end{array}$ & $\begin{array}{l}40- \\
120\end{array}$ & N/A & 2.1 & 100 & 97 & $N / A$ & N/A & $\mathrm{N} / \mathrm{A}$ & 0 & $N / A$ \\
\hline $\begin{array}{l}\text { Pt-Sn } \\
{[115]}\end{array}$ & 250 & $\begin{array}{l}14- \\
22\end{array}$ & 2500 & $10-4$ & $22-43$ & $15-40$ & $3-7$ & 0 & 0 & 0 & N/A \\
\hline $\begin{array}{l}\text { Co-Mo- } \\
\text { S-K [114] }\end{array}$ & 325 & 100 & $6372^{c}$ & N/A & $100 / 72.2 \%{ }^{d}$ & NA & N/A & N/A & $N / A$ & $N / A$ & N/A \\
\hline \multicolumn{12}{|c|}{${ }^{a}$ Referred to all catalysts. } \\
\hline \multicolumn{12}{|c|}{ b Other oxygenates. } \\
\hline \multicolumn{12}{|c|}{${ }^{\mathrm{c}}$ Defined as $\mathrm{L} /\left(\mathrm{kg}_{\mathrm{cat}} \cdot \mathrm{h}\right)$. } \\
\hline \multicolumn{12}{|c|}{${ }^{\mathrm{d}}$ Conversion of acetic acid. } \\
\hline $\mathrm{N} / \mathrm{A}=$ not $\mathrm{a}$ & ilable & & & & & & & & & & \\
\hline
\end{tabular}


The ENSOL process was developed by a joint-venture between Humphreys \& Glasgow Ltd., Monsanto and BASF based on the acetic acid hydrogenation route, but neither a pilot plant nor further research has been done [107]. According to the original scheme of the process, methanol is produced either on-site or off-site using natural gas as feedstock. If methanol is produced on-site, it can be used as raw methanol without enhanced purity [107]. Acetic acid is produced from $\mathrm{CO}$ and methanol, and further converted into ethanol by hydrogenation (see Figure 2). As water is produced in the hydrogenation of acetic acid, a dewatering section is also required in the process [107]. A combination of cryogenic distillation and pressure swing adsorption (PSA) was considered the technical solution to achieve the required purity of $\mathrm{CO}$ and $\mathrm{H}_{2}$ streams [107]. The requirement of high purity $\mathrm{CO}$ and $\mathrm{H}_{2}$ streams represents a disadvantage of this route, since it is intensive in both energy and economy. However, the main limitation for further development of this route lies in the degradation of the catalyst for the acetic acid hydrogenation.

On the basis of reaction data from the Pacific Northwest National Laboratory, which made a technoeconomic assessment of this route, the calculated ethanol minimum selling process was higher than current market price [108,117]. In this assessment, $\mathrm{CO}$ and $\mathrm{H}_{2}$ for both acetic acid production and hydrogenation were assumed as raw materials, i.e. they were not produced from biomass. A new process configuration has been recently described by Jetvic et al. [118].

\subsubsection{Methanol to ethanol via acetic acid esterification}

The acetic acid esterification route comprises a set of different processes in which one mole of acetic acid is esterified with one of alcohol to give one mole of the corresponding ester. The produced ester is easily hydrogenated (hydrogenolysis) to alcohols, yielding two moles of alcohol per mole of ester. One mole of alcohol is used for the esterification of acetic acid, whereas the other would be the product. To our knowledge, only two alcohols have been studied, i.e. methanol and ethanol. Chemical schemes for both cases are shown in Figure 3 and Figure 4. Although this route was developed in the early 1980s only recently have some processes become commercial, such as that by Enerkem Inc. which uses MSW as feedstock $[101,119,120]$.

In this route, acetic acid can be produced as described in 2.1.2., or via "acid carbonylation" (combination of Eq. (8) and Eq. (14)). The first case is applicable for both methanol and ethanol, whereas the second makes sense only if the considered alcohol for the esterification is methanol. The methanol acid carbonylation is close to common acetic acid synthesis but, in this case, it is carried out in acid conditions leading to in situ esterification of part of the generated acetic acid with methanol [121-127]. For acid carbonylation, typical molar selectivity to both acetic acid and methyl acetate is up to $80 \%$, with a 3:1 molar distribution of acetic acid and methyl acetate, respectively $[121,126,127]$. Reaction conditions for the acid carbonylation of methanol are presented in Table 5. The in situ esterification reduces the size of the acetic acid 
esterification section, since a fraction of methyl acetate is produced in the carbonylation reactor. More information about methanol carbonylation over heterogeneous catalysts can be found elsewhere [128-133].

The esterification of methanol and acetic acid is an equilibrium-limited reaction, like most esterification reactions, which can be conducted in regular fixed-bed reactors, but it is normally conducted by reactive distillation [135]. The reactive distillation of acetic acid and methyl acetate is currently the best available technology (BAT) for the production of methyl acetate [136]. The reaction system was developed by the Eastman Kodak Company and it uses an acid catalyst, e.g. sulfuric acid or a sulfonic acid ion exchange resin, for the esterification $[137,138]$.

Esterification of ethanol and acetic acid is also an equilibrium-limited reaction, but in this case, a ternary azeotrope is present $[101,139]$. Industrial production of ethyl acetate can be conducted in batch or CSTR reactors along with several distillation columns [140]. The same considerations as in the esterification with methanol are applicable for the catalyst [139]. There are also studies on vapor-phase esterification, including in a supercritical $\mathrm{CO}_{2}$ atmosphere, but they are not commercially viable $[139,141,142]$.

Table 5. Reaction conditions and product distribution for methanol acid carbonylation catalysts.

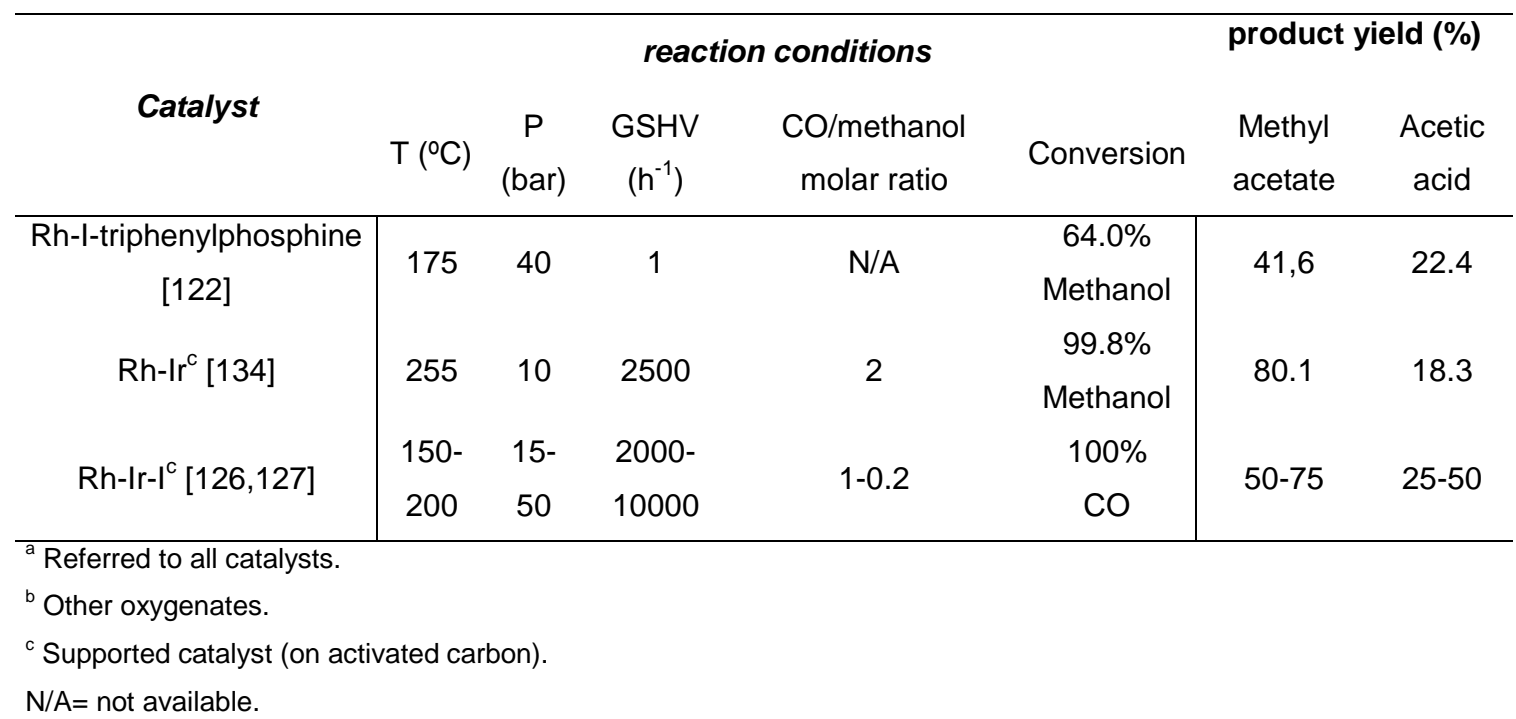




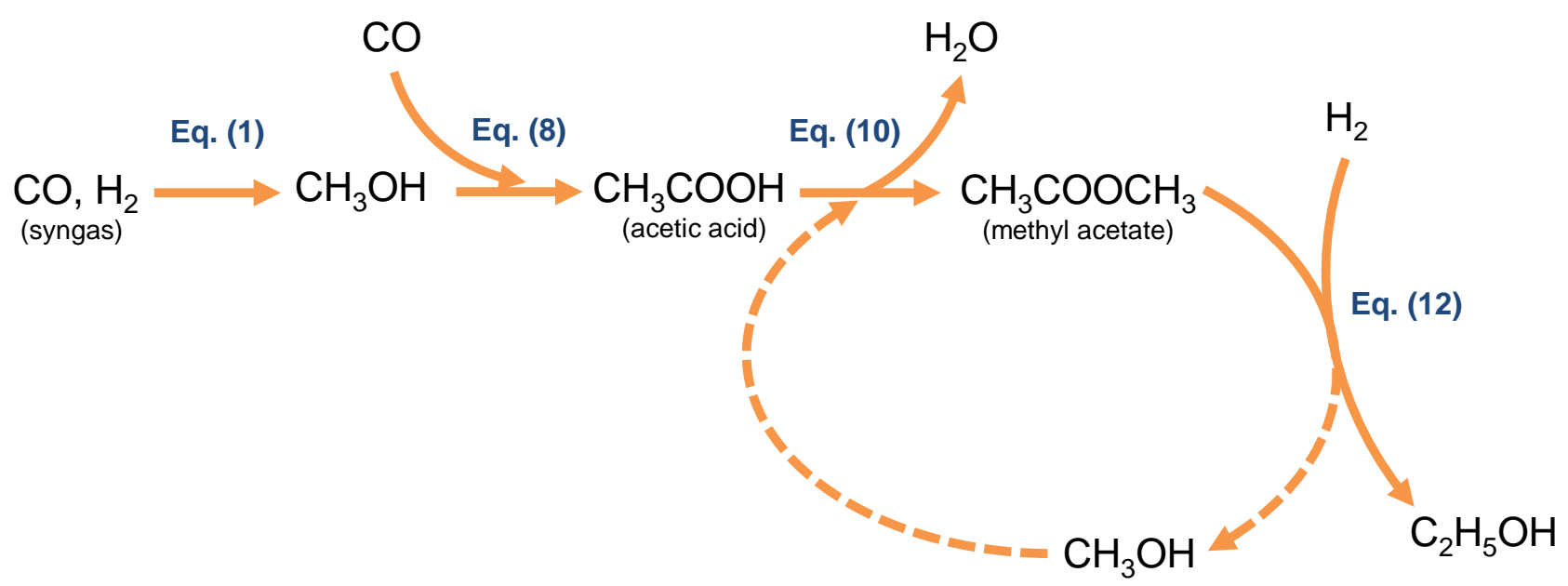

Figure 3. Chemical scheme for the acetic acid esterification with methanol.

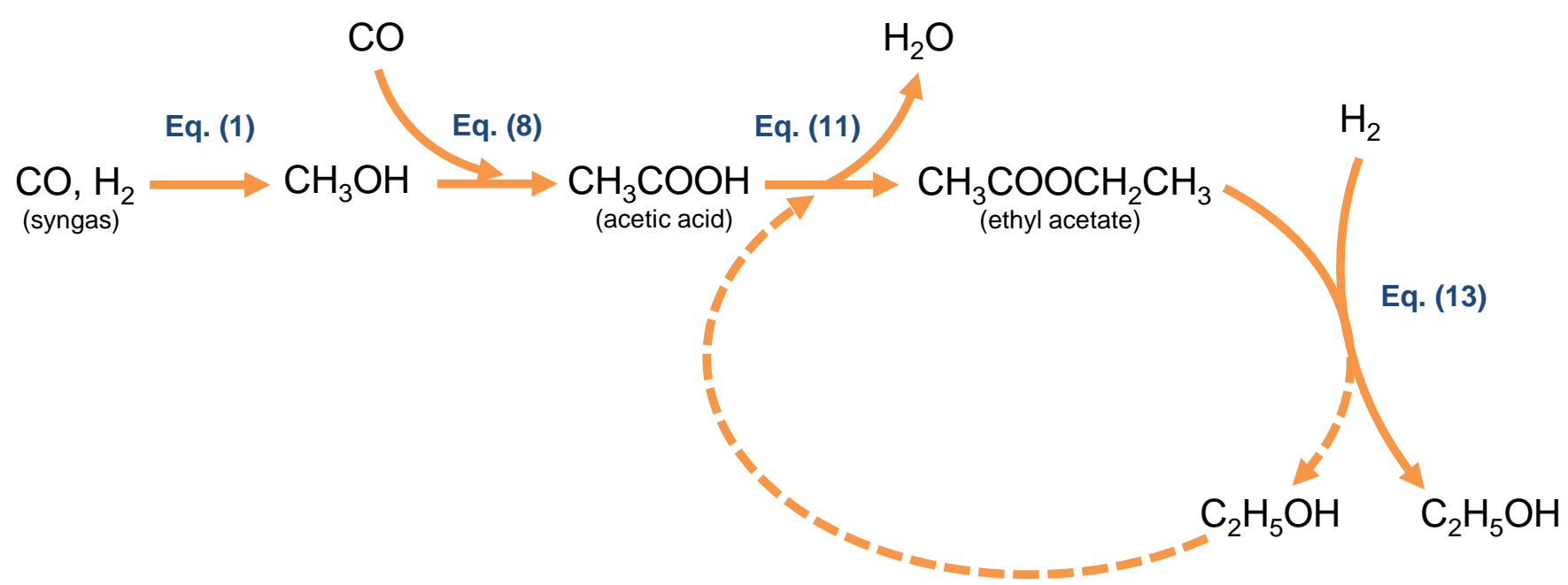

Figure 4. Chemical scheme for the acetic acid esterification with ethanol. 
Hydrogenation (hydrogenolysis) of methyl or ethyl acetate is carried out with heterogeneous catalysts in fixed-bed reactors. Various catalysts have been used for both reactions but at reaction conditions. For common $\mathrm{Cu}-\mathrm{Cr}$ (Adkins) catalysts reaction conditions are severe, i.e. $250-350{ }^{\circ} \mathrm{C}$ and a partial pressure of $\mathrm{H}_{2}$ of $100-300$ bar $[122,143]$. Other catalysts used for acetate hydrogenation are Cu-Fe [144], Re-based [145], Pd-ZnO [146], hydrotalcites [143], Nibased [147] and Rh-based catalysts [148]. Reaction conditions for these catalysts are close to those from the $\mathrm{Cu}-\mathrm{Cr}$ catalyst, but with lower $\mathrm{H}_{2}$ pressures (up to 60 bar) [143]. Ethanol selectivity ranges from 60 to $95 \%$, the main by-products being higher acetates (produced by homologation of the original acetate) and acetaldehyde. However, in these previous studies, acetate hydrogenation (hydrogenolysis) is carried out in the absence of CO. Recent publications based on a $\mathrm{Cu}-\mathrm{ZnO}$ catalyst claim that the hydrogenation of acetates (methyl and ethyl acetates) can be carried out in the presence of $\mathrm{CO}$ with a $\mathrm{H}_{2}$ to $\mathrm{CO}$ molar ratio of 1 , at lower partial pressures of $\mathrm{H}_{2}(<15 \mathrm{bar}$ ) and with similar or higher selectivity to corresponding alcohols [149-151].

The Halcon SD Group proposed a process based on the acetic acid esterification route for the production of ethanol using methanol and natural gas as feedstock [101]. In this process, methanol is carbonylated to produce acetic acid using a proprietary technology similar to Monsanto's process. Esterification of acetic acid is carried out with methanol recycled from the hydrogenation section using proprietary technology (Eastman Kodak). Produced methyl acetate is hydrogenated to yield an equimolar mixture of methanol and ethanol. $\mathrm{CO}$ and $\mathrm{H}_{2}$ for the process are produced by reforming natural gas [101]. BASF AG proposed another alternative based on this route which used acid carbonylation (see Table 5) [122]. In this process, methanol is carbonylated to yield a mixture of methyl acetate, acetic acid, DME, and to a lesser extent, ethanol and propionic acid [122]. Produced methyl acetate is then hydrogenated, as commented before. In this process, acetic acid from the acid carbonylation is recycled to the carbonylation reactor for total conversion to methyl acetate. There are other process alternatives such as that by the Korea Institute of Science and Technology, which proposed a supported catalyst for the acid carbonylation of methanol with no recycling of acetic acid [134].

Recently, Enerkem Inc. has proposed the modification of previous BASF and Korea Institute of Science and Technology processes by adding a stage for acetic acid esterification in order to achieve complete conversion to methyl acetate [126]. In this process, methanol is carbonylated to a mixture of methyl acetate and acetic acid in the vapor phase using a fixed bed reactor packed with a rhodium-based catalyst [127]. Acetic acid is further esterified with methanol by reactive distillation yielding methyl acetate. Methanol from the hydrogenation of methyl acetated is recycled to esterification section. If ethanol is used instead of methanol for the esterification, only ethanol would be produced (hydrogenation of ethyl acetate, Eq. (13)) and no distillation of the methanol/ethanol mixture would be required. However, the use of ethanol does not result in the reduction of costs, due to the greater complexity of the acetic acid esterification [101]. 
Enerkem has announced that they expect to produce competitive bioethanol in the short term with their process [120].

\subsubsection{Methanol/DME to methyl acetate via DME carbonylation}

The DME carbonylation route relates the production of methyl acetate through DME by using only heterogeneous catalysts. This route is based on the capability of some catalysts, e.g. zeolites, to synthetize methyl acetate from CO and DME. The carbonylation of DME to yield methyl acetate is a new and active field of research [152]. Although this route can be integrated with acetic anhydride production (see 2.1.6.), it is preferable to discuss each one separately, since they are focused on a different product. Methyl acetate is currently available as a subproduct in the commercial production of acetic acid or produced by reactive distillation from acetic acid and methanol [153]. The uses of methyl acetate are as a solvent (substitute for acetone), and for the production of acetic anhydride $[154,155]$.

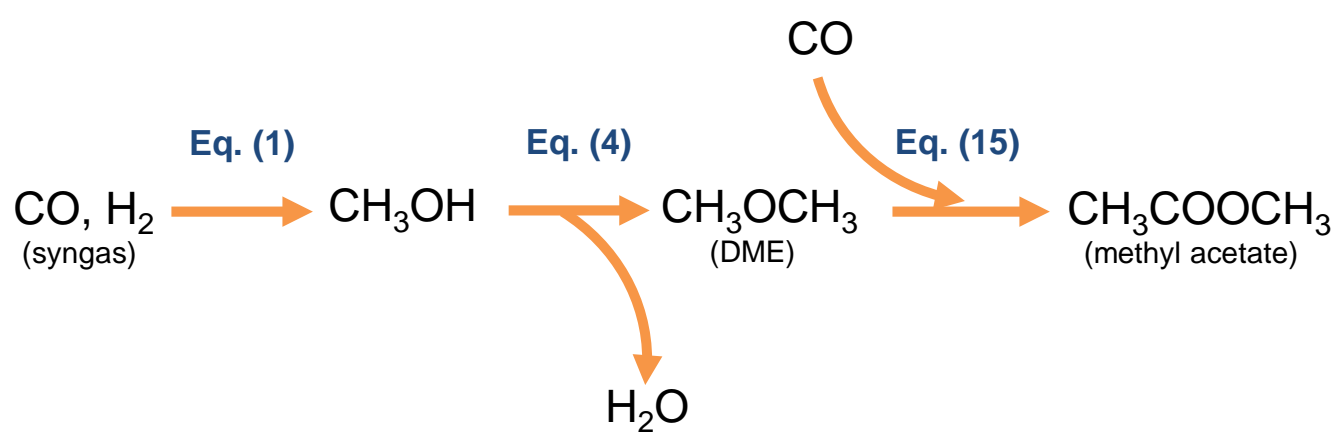

Figure 5. Chemical scheme for DME carbonylation.

The DME carbonylation route comprises the combination of DME synthesis and DME carbonylation (Eq. (15)), as shown in Figure 5. Syngas is used for DME synthesis (see 2.1.) and to provide $\mathrm{CO}$ for the carbonylation of DME, which (depending on the syngas composition and plant configuration) normally leads to a net production of $\mathrm{H}_{2}$.

The carbonylation of DME occurs in the presence of some kinds of zeolites, e.g. mordenites, ferrierites and ZSM-35, at reaction conditions of up to 100 bar and $150-200{ }^{\circ} \mathrm{C}[131,156,157]$. The carbonylation reaction is said to be conducted with a stable rate and without significant catalyst deactivation $[131,156]$. Presence of water in the reaction mixture decreases methyl acetate formation and slightly increases that of methanol. This is because of the competition of water for the active sites of the zeolite $[131,152]$. However, this effect is reversible and does not deactivate the catalyst [131]. Methyl acetate synthesis rates are proportional to CO pressure and independent of DME [131]. DME carbonylation is primarily conducted in 8-MR channels, in the case of mordenites, or in 10-MR channels, in the case of ZSM-35 $[156,157]$. There is a possible deactivation due to coke formation on the catalyst $[132,157]$. Details for the kinetics of the DME carbonylation are given elsewhere $[133,152,156,158]$. The DME carbonylation route has been technoeconomically assessed along with the DME hydrocarbonylation route (see 
2.1.5.) [44]. Results showed that methyl acetate can be produced economically from lignocellulosic biomass.

\subsubsection{Methanol/DME to ethanol via DME hydrocarbonylation}

The DME hydrocarbonylation route is the most recent attempt to find a feasible technoeconomic route to produce ethanol from lignocellulosic biomass [44,52,149-151,159]. The DME hydrocarbonylation route is an extension of the DME carbonylation route (2.1.4.), where a hydrogenation step is added leading to ethanol production. In this route, produced methyl acetate is hydrogenated (see 2.1.3.) to yield methanol, which is recycled to complete conversion, and ethanol. For ethanol production, the DME hydrocarbonylation route outweighs the above described processes focused on ethanol production (with acetic acid as intermediate), since the number of process steps is lower and only heterogeneous catalysts are employed.

The DME hydrocarbonylation route (Figure 6) comprises the following steps (some alternatives are possible): DME synthesis (see 2.1.), DME hydrocarbonylation (Eq. (16)) and methanol dehydration (Eq. (4)). The hydrocarbonylation of DME has been studied in a dual catalytic bed reactor, where catalysts for carbonylation of DME and hydrogenation of methyl acetate were placed in series [149-151,159]. Results of these studies show that the hydrocarbonylation can be effectively conducted at $220^{\circ} \mathrm{C}$ and 15 bar using the combination of a first catalytic bed of $\mathrm{H}$ Mordenite and a second catalytic bed of Cu-ZnO [149-151].

The DME hydrocarbonylation route has been technoeconomically assessed [44,52]. The results showed that the DME hydrocarbonylation route is cost-competitive for ethanol production from lignocellulosic biomass, due to the mild reaction conditions and high global selectivity to ethanol.

\subsubsection{Methanol/DME to acetic anhydride via methyl acetate carbonylation}

The methyl acetate carbonylation route was developed in the 1980s in an attempt to overcome the ketene process in the synthesis of acetic anhydride $[136,160]$. Acetic anhydride is one of the most important organic intermediates in the industry and it is used for the production of cellulose acetate and as a precursor of vinyl acetate monomer [161]. In the methyl acetate carbonylation route, acetic anhydride is produced through acetic acid (Eq. $(8,10))$ or DME (Eq. $(4,15))$, which leads to the two alternatives shown in Figure 7. Acetic anhydride production through acetic acid represents, along with the ketene process, the main commercial means of acetic anhydride production $[136,161]$.

The carbonylation of methyl acetate is a process derived from methanol carbonylation (see 2.1.2.), using Rh-based homogeneous catalysts. In methyl acetate carbonylation, $\mathrm{H}_{2}$ has to be present as a reduction agent for the catalyst, and also to avoid acetic anhydride hydrolysis. 
Other differences between methyl acetate and methanol carbonylation relate to the choice of promoters (Lil) and the reaction mechanism, as described by Zoeller $[136,162]$.

The Eastman Kodak Company, in collaboration with the Halcon SD Group, proposed the first commercial process using methyl acetate carbonylation. The process aimed to use coal as feedstock and the final product would be cellulose acetate $[136,160]$. In this process, methyl acetate reacts with $\mathrm{CO}$ to yield acetic anhydride which is converted in the plant into cellulose acetate. Reaction of acetic anhydride and cellulose leads to the production of acetic acid as a by-product, which is used for the esterification with methanol [136].

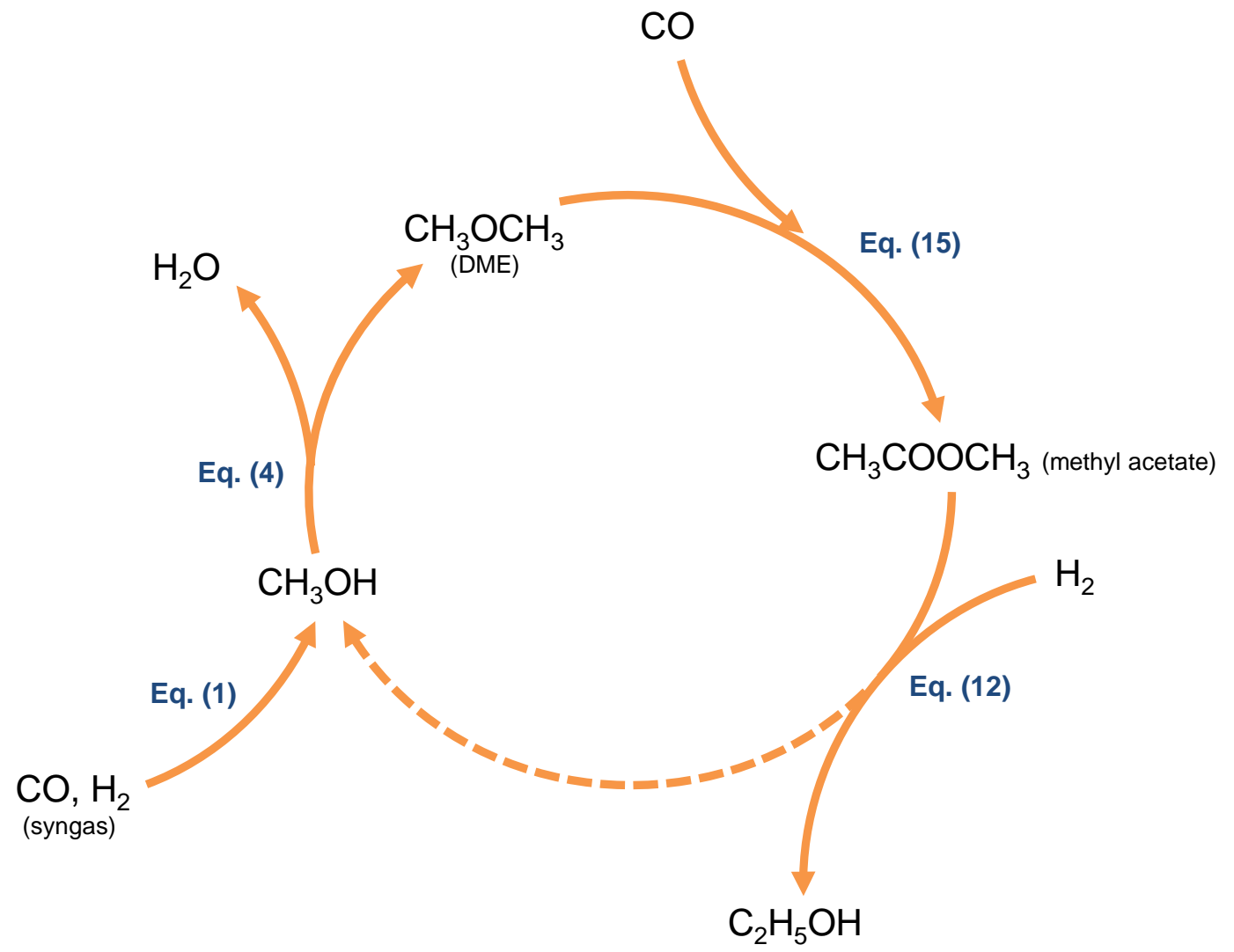

Figure 6. Chemical scheme for the DME hydrocarbonylation route. Adapted from Haro et al. [44].

The dashed line means recycling.

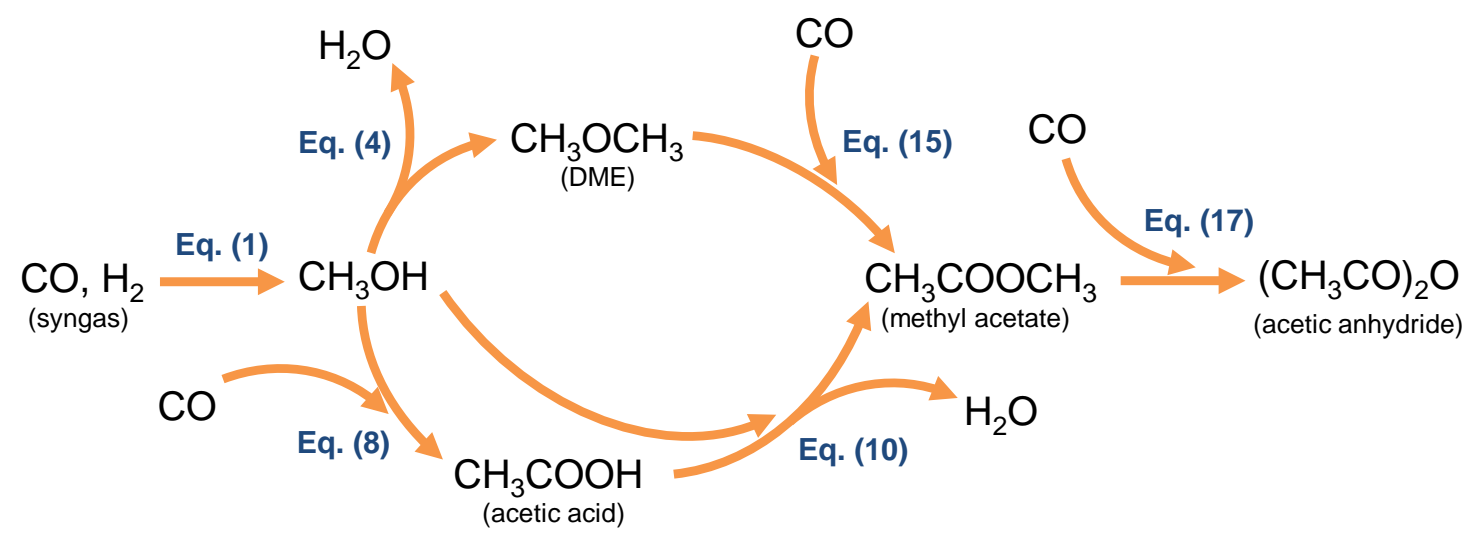

Figure 7. Chemical scheme for methyl acetate carbonylation through DME. 


\subsubsection{Methanol to ethanol via acetic acid esterification}

The acetic anhydride esterification route was proposed by the Halcon SD Group in the 1980s $[101,160,163]$. This route relates to the capability of acetic anhydride to yield acetates via esterification with alcohols. Several process configurations are applicable to this route, but only two are appealing. In both configurations the main product is ethanol. However, neither has been commercialized or further investigated.

In the first alternative, methanol reacts with acetic acid (see 2.1.3.) to form methyl acetate, which is then converted into acetic anhydride by carbonylation with CO (Eq. (17), see 2.1.6.) [163]. The acetic anhydride is esterified with ethanol (Eq. (18)) to yield ethyl acetate and acetic acid. Acetic acid is recycled to the first esterification (Eq. (10)), whereas ethyl acetate is hydrogenated to ethanol (Eq. (13)). A fraction of generated ethanol is used for the esterification with acetic anhydride (see 2.1.3). Figure 8 shows the chemical scheme in the case of acetic acid esterification with ethanol.

In the second alternative, an equimolar mixture of methanol and ethanol react with acetic anhydride to yield a mixture of methyl and ethyl acetate, (Eq. (19) and (18)) [101]. Methyl acetate is recycled for acetic anhydride production (Eq. (17)) and ethyl acetate hydrogenated (Eq. (13)) to yield ethanol as a product.

\subsubsection{Methanol/DME to gasoline}

The methanol-to-gasoline (MTG) route was developed in the 1980s in response to the crude oil crisis. The considered feedstock was natural gas, as a substitute to crude oil, which made the process especially attractive for isolated locations with access to natural gas $[164,165]$. The first commercial plant based on the MTG route was constructed in New Zealand (1985) using fixedbed technology [166]. Other facilities were constructed, but most of them were shut down when crude oil prices made the process unprofitable [164]. DME can also be used (and is sometimes preferred for the thermal integration of the reactor) as the chemical intermediate for conversion to gasoline [167]. At present, there is new interest on this route, not focused only on natural gas as the feedstock but also on coal and biomass. Exxon Mobile and Haldor Topsoe are the most important licensors of this technology.

Kinetics for methanol/DME to gasoline conversion is described elsewhere (focused on methanol conversion) $[164,168,169]$. Methanol/DME to gasoline conversion is a complex reaction pattern of methylation, oligomerization, hydrocarbon formation and cracking using zeolites as catalysts $[168,169]$. Further discussion on process technologies and other aspects such as catalyst deactivation can be found in Olsbye et al. [166]. The conversion of methanol/DME into gasoline results in light gases, hydrocarbons in the light and heavy gasoline range, and water. The most problematic compound of the heavy gasoline fraction is durene (1,2,4,5-tetramethyl-benzene) which needs to be further processed in order to meet current gasoline specifications [170]. The 
upgraded heavy gasoline is blended with the light gasoline fraction to give commercial grade gasoline.

Both fixed-bed and fluidized bed technologies have been proven for the MTG route in commercial plants. Details of process design and plant economics are given elsewhere $[164,165,171]$. Technoeconomic assessments on gasoline production from lignocellulosic biomass have been recently published $[21,170,172,173]$.

\subsubsection{Methanol/DME to olefins}

The methanol/DME to olefins (ethylene and propylene) route was developed simultaneously with the methanol/DME to gasoline route and both routes have important similarities $[164,172]$. Regarding conversion section, UOP has developed the so-called methanol-to-olefins (MTO) process using a fluidized catalytic reactor $[164,166,168]$. This design is the best available technology for methanol conversion to olefins [164].

Details for the kinetics and reaction conditions for the methanol/DME conversion into olefins are presented elsewhere [164,166-169]. In general, catalysts (zeolites) for the production of olefins are characterized by smaller pore sizes compared to the production of gasoline [169]. Lower partial pressures of DME and higher reaction temperatures lead to a shift in the product distribution to lighter hydrocarbons [167]. The main products are ethylene and propylene, making up about $84 \%$ on mass basis of total hydrocarbons produced $[164,174]$.

This route has been recently assessed [172]. Results showed that olefins could be produced efficiently from lignocellulosic biomass but at higher costs than current production, mainly due to the feedstock price.

\subsubsection{Methanol/DME to fuels (gasoline, diesel and jet fuel)}

In this route, olefins are converted into hydrocarbons in the range of gasoline, diesel and jet fuel. The conversion of olefins can be conducted in a fixed-bed reactor at variable reaction conditions which leads to different productions of each fraction. A description of such a process is given by Avidan and was developed by Mobil [164,175]. Despite the greater complexity of this route, the gasoline fraction is usually better quality, as the durene content is lower compared to gasoline produced via the MTG route (2.1.8.) $[164,169,175]$. However, there is a lack of public information on specific reaction conditions and process configuration. 


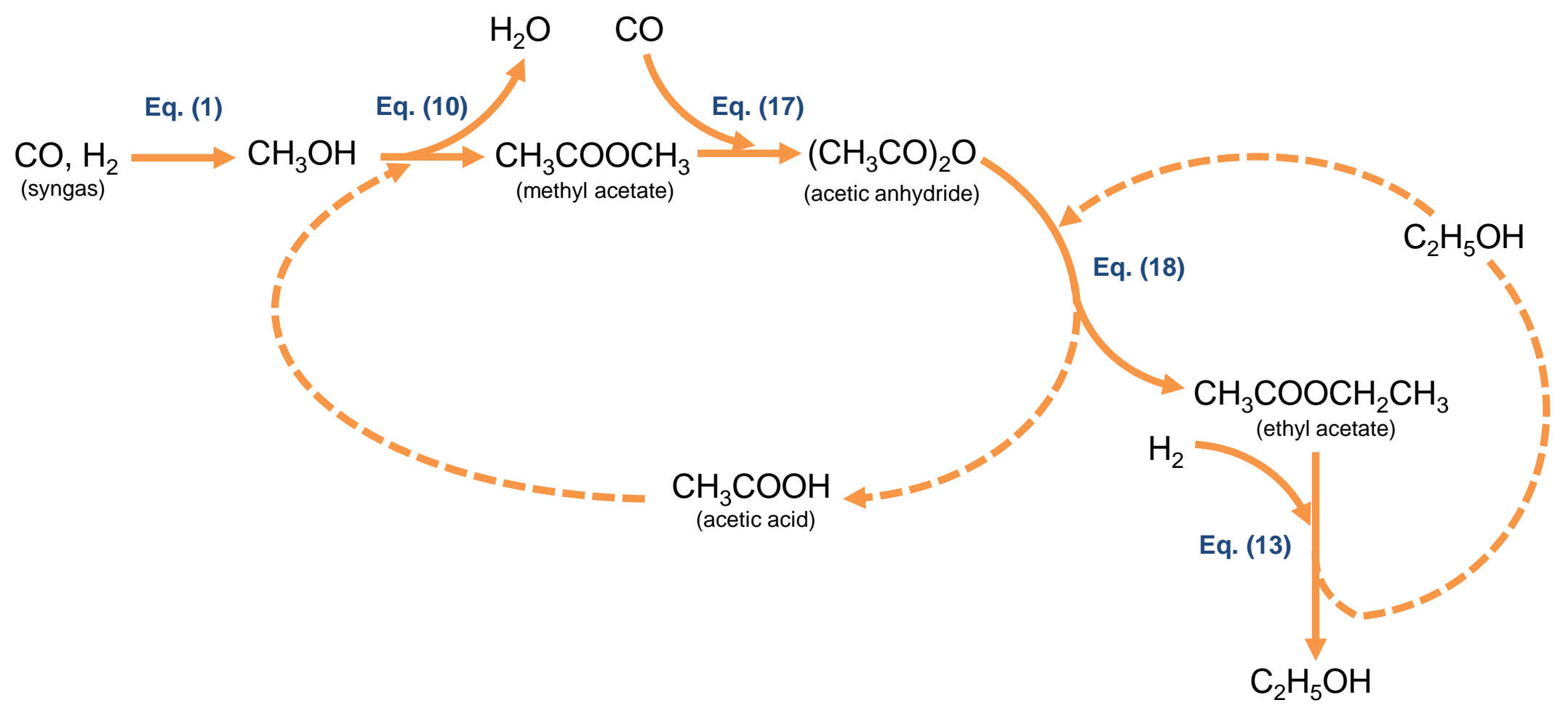

Figure 8. Chemical scheme for the acetic anhydride esterification route (with ethanol). Dashed lines mean recycling. 


\subsection{Ethanol as a platform chemical}

The following routes relate to the use of ethanol as a platform chemical. Obviously, these routes are independent of the origin of ethanol, which could come from lignocellulosic biomass $\left(2^{\text {nd }}\right.$ generation processes), e.g. from sugar cane, corn or sugar beet ( $1^{\text {st }}$ generation processes), or even from a fossil feedstock, as commented in 2.1.1., 2.1.2., 2.1.3. and 2.1.5. Hence, the discussion will include the processing of all kinds of ethanol regardless of their provenance.

\subsubsection{Ethanol dehydration to ethylene}

The ethanol dehydration route relates to the production of ethylene using ethanol. There is growing interest in this route, since the apparent relatively low-cost of bioethanol makes it attractive for chemical synthesis [176]. Ethylene production from ethanol represents one of the most feasible options at present from both a technical and economic point of view [177]. The dehydration of ethanol is an established technology which is commercially available $[176,178]$. Some industrial projects are currently being carried out [179].

The dehydration of ethanol (Eq. (20), Figure 9) is conducted at $180-400^{\circ} \mathrm{C}$ and atmospheric pressure achieving selectivities of over 95\% to ethylene [176,179-183]. As in the case of methanol dehydration (see 2.1.), zeolites are the preferred catalyst for ethanol dehydration, but a carbon-based catalyst has also been studied [180,184]. Main by-products depend on the employed catalyst, but the most cited are ethane, propylene, butylene and diethyl-ether $[178,180,181]$. Presence of water in the reaction mixture has an important effect on selectivity to by-products and on ethanol conversion $[180,181]$. Water prevents catalyst deactivation due to coke formation [180]. Details on the kinetic and process conditions can be found elsewhere $[180-183,185]$.

The BETE (bioethanol-to-ethylene) process was studied in the 1980 s as an attempt to use raw ethanol from $1^{\text {st }}$ generation processes as feedstock [185]. However, there is no new information about this process. Currently, there are several projects in Brazil, due to the availability of lowcost ethanol $[176,186]$. A technoeconomic assessment for ethylene production using bioethanol as feedstock has been recently carried out [187].

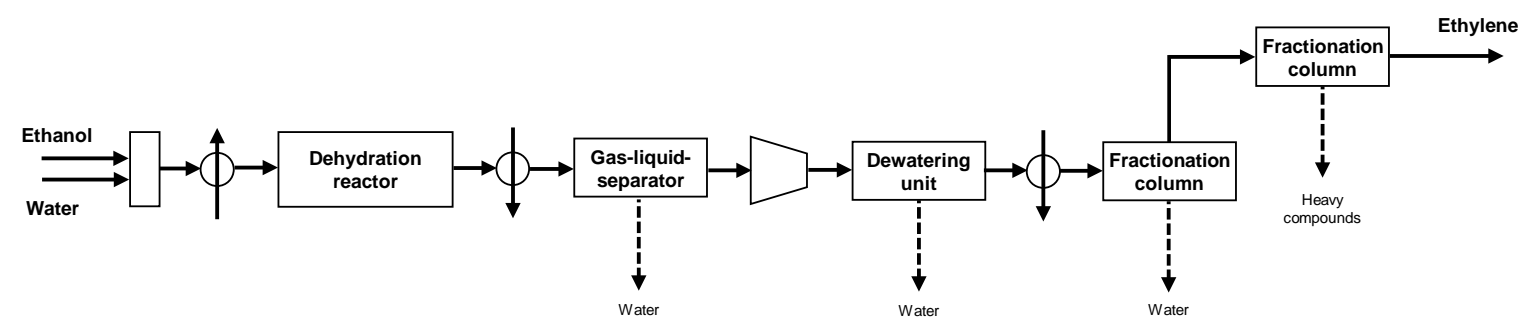

Figure 9. Conceptual diagram for the ethanol dehydration route. 


\subsubsection{Ethanol to propylene}

Propylene can be produced from ethanol [188]. In this route, the ethanol feedstock is dehydrated to ethylene (see 2.2.1.) and then a portion of ethylene is dimerized to produce normal butene. The butenes are then reacted with the remaining ethylene via the metathesis reaction to produce propylene [188]. The chemistry of olefins metathesis is described elsewhere $[189,190]$.

\subsubsection{Ethanol to butanol}

Recently, some companies have focused their efforts on the production of renewable butanol from ethanol, because of the enhanced properties of butanol as a gasoline substitute and as a chemical precursor [191]. The conversion of ethanol to butanol (Eq. (21)) is called catalytic condensation, dimerization or reductive dehydration. Some catalysts are active for the reaction: MgO [192], hydroxyapatites [193,194], Cu-Mg-Al mixed oxides [195] and hydrotalcites $[196,197]$. Depending on the selected catalyst, the reaction is conducted at temperatures ranging from 250 to $450^{\circ} \mathrm{C}$ and atmospheric pressures [192-195,197]. Details of ethanol conversion to butanol are given elsewhere [192-198]. Technological development of this route is still limited and public technoeconomic assessments on the routes are scarce [199].

Butanol can be further processed for the production of renewable jet fuel and chemicals but further research is still needed to optimize process conditions and quality of the fuel [200-202].

\subsubsection{Ethanol dehydrogenation to ethyl acetate}

Ethanol can be dehydrogenated to yield ethyl acetate, i.e. the reverse reaction to Eq. 13 (see 2.1.7.). The chemistry basis of ethanol dehydrogenation is analogous to reverse hydrogenation; details are given elsewhere [203-205]. The production of ethyl acetate from renewable ethanol using the technology licensed by Kvaerner Process Technology Ltd. has been recently reported indicating that the route could be cost competitive [206,207].

\subsubsection{Other routes to chemicals}

Important efforts are being made for the conversion of ethanol into a wide range of hydrocarbons, e.g. gasoline and aromatics, following similar processing to the methanol case. Information of this processing can be found elsewhere [208-213].

\subsection{Other platforms chemicals}

As shown earlier, there is limited development of thermochemical routes via platform chemicals. To date, only methanol, DME and ethanol have been considered platform chemicals, but there are other potential compounds of interest, e.g. butanol and methane. The conversion of light hydrocarbons to high-value compounds could be one example, although these efforts are 
focused on the use of natural gas as feedstock. Currently research is being conducted into the efficient conversion of methane into methanol [214-216].

\section{Discussion}

The review provides a variety of routes via platform chemicals to be taken into account for the design of thermochemical biorefineries. However, it is still necessary to define the methods leading to these routes (they were first studied some time ago) because they could be used in a multi-production plant. For this propose, an example of design is given, based on the use of DME as a platform chemical. Since the reviewed routes were developed for the use of fossil feedstock instead of biomass and waste, the impact of the change in syngas composition needs to be clarified, e.g. in the case of natural gas as original feedstock. This and other preliminary questions for the further design of thermochemical biorefineries are introduced.

\subsection{Example of thermochemical biorefinery}

An example of thermochemical biorefinery based on routes via platform chemicals has been recently proposed by Haro et al. [44]. In this assessment, the DME carbonylation (see 2.1.4.) and hydrocarbonylation (see 2.1.5.) routes were selected to bring up to two sets of thermochemical biorefinery concepts. Potential products considered in that study were: methyl acetate, $\mathrm{H}_{2}$, DME and electric power (DME carbonylation), and ethanol, $\mathrm{H}_{2}$, DME and electric power (DME hydrocarbonylation). The study proved that concepts based on routes via platform chemicals have better or at least similar economics to BTL/G processes, despite their greater complexity [44]. In addition, a previous study [52] confirmed that the DME hydrocarbonylation route can overcome the limitation of the direct synthesis of ethanol from without a negative effect on economics $[4,5,20,55,217]$.

\subsection{Impact of feedstock selection of the mix of products}

The impact of using lignocellulosic biomass or carbon-based waste instead of other fossil fuels raises two important considerations regarding the design of thermochemical biorefineries.

First, each feedstock (coal, natural gas, biomass or carbon-based waste) processing (gasification) leads to a different syngas composition, i.e. different $\mathrm{H}_{2} / \mathrm{CO}$ molar ratios, which must be compared with the optimum $\mathrm{H}_{2} / \mathrm{CO}$ ratio required in each route. For the single production of ethanol the optimum $\mathrm{H}_{2} / \mathrm{CO}$ ratio would be 2 (2.1.1., 2.1.2., 2.1.3., 2.1.5., 2.1.7.), except for the Dry Ethanol Process in 2.1.1. (with a ratio of 0.5). For the single production of gasoline and olefins from methanol/DME (2.1.8., 2.1.9.) the ratio is also 2. However, in the case of single methyl acetate production (2.1.4.) the ratio would be 1.33, and 1 in the case of acetic anhydride (2.1.6.). Finally, in the case of ethanol as a platform chemical, only in the case of ethanol dehydrogenation to ethyl acetate (2.2.4.) the ratio would be 1.5 instead of 2 . If single production is sought, then natural gas (which presents $\mathrm{a}_{2} / \mathrm{CO}$ ratio of 3 ) would be more appealing than coal, biomass or carbon-based waste as feedstock, which leads to much lower 
ratios in the syngas $(0.5-1.0)$; and therefore, some routes via platform chemicals were intended to use natural gas according to the given description. Furthermore, the $\mathrm{H}_{2}$ excess in the processing leads to a net production of $\mathrm{H}_{2}$. In the case of lower $\mathrm{H}_{2} / \mathrm{CO}$ ratios using other feedstock, the water gas shift (WGS) reaction is usually the best option to achieve enhanced conversion to products, but with an important reduction of carbon and energetic efficiency. However, as thermochemical biorefineries are focused on multi-production, a lack of $\mathrm{H}_{2}$ could be overcome by a balanced design of the mix of co-products, i.e. what and in which amount will be produced from syngas within the thermochemical biorefinery. An example is given in 3.1., where ethanol production (which requires a ratio of 2) was compensated with DME production (which requires a ratio of 1 ).

Second, it seems clear that beside syngas generation and conditioning, the most important differences within the feedstock relate to availability, price and sustainable nature. These factors should be balanced by simultaneously assessing the economics and sustainability of the process. In the case of carbon-based waste, e.g. plastics, they are usually derived from crude oil so should not be classified as a neutral carbon feedstock. However, their growing volume represents a problem in landfills and recycling suffers from a technical and economic mismatch. The use of MSW in thermochemical processing may be an interesting option to be assessed. Another opportunity would be the study of co-feeding, i.e. combination of carbon neutral and other feedstock, such as plastics, natural gas or coal. Some authors have studied the subject, but further research is still necessary [219-224].

\subsection{Further research on thermochemical biorefineries}

In the opinion of the authors, studies on thermochemical biorefineries need common criteria for sustainability and comprehensive life cycle assessment (LCA) methodology, which include the specificity of the multi-production, fossil and waste feedstock co-feeding, and the integration of carbon capture and sequestration (CCS) technologies. The removal of $\mathrm{CO}_{2}$ in a plant using carbon neutral feedstock would lead to negative GHG emissions, ready to be sold as $\mathrm{CO}_{2}$ certificates. Hence, there is an opportunity in thermochemical biorefineries and common BTL/G processes to improve economics and/or fulfill sustainability if co-feeding is considered. These proposals should be performed in current and upcoming assessments of thermochemical biorefineries. 


\section{Conclusions}

The use of recent and old-fashioned routes via a platform chemical facilitates the design of new concepts of thermochemical biorefineries. The reviewed routes demonstrate to be capable for the (simultaneous) multi-production of chemicals and fuels and therefore they serve as a keystone for the future designs of thermochemical biorefineries. Despite the lack of technoeconomic assessments based on these routes the results from a recent publication show that they could be profitable if the mix of co-products is well selected [44]. The presented routes bring a wider range of potential bio-products, both chemicals and commodities, different to those considered up to date and therefore allow more possibilities for the selection of the mix. The fact that the reviewed routes could be applied to a fossil feedstock, e.g. coal and natural gas, is a natural consequence of the concept of a thermochemical biorefinery and an advantage, since both the technology and the know-how from the processing of fossil feedstocks can be adapted and integrated in a thermochemical biorefinery. Finally, some guides for the further work on thermochemical biorefineries are given like the need of a minimum basis of agreement on LCA methodology and sustainability criteria.

\section{Acknowledgements}

This review has been funded by the Spanish Ministry of Economy and Competitiveness and carried out in the framework of the project "BIOTER" (Proyecto de Investigación Fundamental No-Orientada; ENE2012-31598). The grant given by the Spanish Ministry of Education (FPU Program; AP2010-0119) to P. Haro is acknowledged. 


\section{References}

[1]. New Commission proposal to minimise the climate impacts of biofuel production. European Commission Press Release (Reference: IP/12/1112 Event Date: 17/10/2012) http://europa.eu/rapid/press-release_IP12-1112_en.htm [accessed October 2012]

[2]. Sims REH, Mabee W, Saddler JN, Taylor M, An overview of second generation biofuel technologies. Bioresour Technol. 101(6):1570-80 (2010).

[3]. Menon V, Rao M, Trends in bioconversion of lignocellulose: Biofuels, platform chemicals \& biorefinery concept. Prog Energy Combust Sci. 38(4):522-50 (2012).

[4]. Subramani V, Gangwal SK, A review of recent literature to search for an efficient catalytic process for the conversion of syngas to ethanol. Energy and Fuels. 22(2):814-39 (2008).

[5]. Spivey JJ, Egbebi A, Heterogeneous catalytic synthesis of ethanol from biomass-derived syngas. Chem Soc Rev. 36(9):1514-28 (2007) (2007).

[6]. Zinoviev S, Müller-Langer F, Das $P$, Bertero N, Fornasiero $P$, Kaltschmitt $M$, et al. Next-generation biofuels: Survey of emerging technologies and sustainability issues. ChemSusChem. 3(10):1106-33 (2010).

[7]. Zhang W, Automotive fuels from biomass via gasification. Fuel Process Technol. 91(8):866-76 (2010).

[8]. Floudas CA, Elia JA, Baliban RC, Hybrid and single feedstock energy processes for liquid transportation fuels: A critical review. Comput Chem Eng. 41:24-51 (2012).

[9]. Tijmensen MJA, Faaij APC, Hamelinck CN, Van Hardeveld MRM. Exploration of the possibilities for production of fischer tropsch liquids and power via biomass gasification. Biomass Bioenerg. 23(2):12952 (2002).

[10]. Hamelinck CN, Faaij APC, den Uil H, Boerrigter H, Production of FT transportation fuels from biomass; technical options, process analysis and optimisation, and development potential. Energy. 29(11):1743-71 (2004).

[11]. Zwart RWR, Boerrigter H. High efficiency co-production of synthetic natural gas (SNG) and fischertropsch (FT) transportation fuels from biomass. Energy and Fuels. 19(2):591-7 (2005).

[12]. Kreutz TG, Larson ED, Liu G, Williams RH, In: Fischer-Tropsch fuels from Coal and Biomass. $25^{\text {th }}$ Annual International Pittsburgh Coal Conference, PCC - proceedings, 29 September - 2 October (2008).

[13]. Larson ED, Jin H, Celik FE. Large-scale gasification-based coproduction of fuels and electricity from switchgrass. Biofuel Bioprod Bioref. 3(2):174-94 (2009).

[14]. Meerman JC, Ramírez A, Turkenburg WC, Faaij APC, Performance of simulated flexible integrated gasification polygeneration facilities. Part A: A technical-energetic assessment. Renew Sust Energ Rev. 15(6):2563-87 (2011).

[15]. Meerman JC, Ramírez A, Turkenburg WC, Faaij APC. Performance of simulated flexible integrated gasification polygeneration facilities, part B: Economic evaluation. Renew Sust Energ Rev. 16(8):6083102 (2012).

[16]. Trippe F, Fröhling M, Schultmann F, Stahl R, Henrich E, Dalai A, Comprehensive techno-economic assessment of dimethyl ether (DME) synthesis and Fischer-Tropsch synthesis as alternative process steps within biomass-to-liquid production. Fuel Process Technol. 106:577-86 (2012).

[17]. Phillips SD, Technoeconomic analysis of a lignocellulosic biomass indirect gasification process to make ethanol via mixed alcohols synthesis. Ind Eng Chem Res. 46(26):8887-97 (2007).

[18]. Zhu Y, Gerber MA, Jones SB, Stevens DJ, Analysis of the Effects of Compositional and Configurational Assumptions on Product Costs for the Thermochemical Conversion of Lignocellulosic Biomass to Mixed Alcohols - FY 2007 Progress Report, Pacific Northwest National Laboratory, December 2008.

[19]. Dutta A, Phillips S, Thermochemical ethanol via direct gasification and mixed alcohol synthesis of lignocellulosic biomass. NREL/TP-510-45913 (2009). http://www.nrel.gov/docs/fy07osti/41168.pdf 
[20]. Villanueva Perales AL, Reyes Valle C, Ollero P, Gómez-Barea A, Technoeconomic assessment of ethanol production via thermochemical conversion of biomass by entrained flow gasification. Energy. 36(7):4097-108 (2011).

[21]. Phillips SD, Tarud J, Biddy M, Dutta A, Gasoline from Wood via Integrated Gasification, Synthesis, and Methanol-to-Gasoline Technologies. Golden, CO: National Renewable Energy Laboratory (NREL). Report No.: NREL/TP-5100-47594 (2011). http://www.nrel.gov/docs/fy11osti/47594.pdf

[22]. He J, Zhang W, Techno-economic evaluation of thermo-chemical biomass-to-ethanol. Appl Energy. 88(4):1224-32 (2011).

[23]. Dutta A, Talmadge M, Hensley J, Worley M, Dudgeon D et al. Process Design and Economics for Conversion of Lignocellulosic Biomass to Ethanol: Thermochemical Pathway by Indirect Gasification and Mixed Alcohol Synthesis. Golden (CO): National Renewable Energy Laboratory; 2011 May. Report No.: NREL/TP-5100-51400, Contract No.: DE-AC36-08GO28308. Sponsored by the Department of Energy (2011).

[24]. Dutta A, Talmadge M, Hensley J, Worley M, Dudgeon D, Barton D, et al. Techno-economics for conversion of lignocellulosic biomass to ethanol by indirect gasification and mixed alcohol synthesis. Environ Prog Sustain Energy. 31(2):182-90 920128.

[25]. Katofsky RE, The production of fluid fuels from biomass. Princeton University, Center for Energy and Environmental Studies, Report No. 279 (1993).

[26]. Hamelinck CN, Faaij APC. Future prospects for production of methanol and hydrogen from biomass. J Power Sources. 111(1):1-22 (2002).

[27]. Yin X, Leung DYC, Chang J, Wang J, Fu Y, Wu C, Characteristics of the synthesis of methanol using biomass-derived syngas. Energy and Fuels. 19(1):305-10 (2005).

[28]. Clausen LR, Houbak N, Elmegaard B, Technoeconomic analysis of a methanol plant based on gasification of biomass and electrolysis of water. Energy. 35(5):2338-47 (2010).

[29]. Clausen LR, Elmegaard B, Ahrenfeldt J, Henriksen U, Thermodynamic analysis of small-scale dimethyl ether (DME) and methanol plants based on the efficient two-stage gasifier. Energy. 36(10):5805-14 (2011).

[30]. van Rens GLMA, Huisman GH, de Lathouder H, Cornelissen RL, Performance and exergy analysis of biomass-to-fuel plants producing methanol, dimethylether or hydrogen. Biomass Bioenerg. 35(SUPPL. 1):S145-54 (2011).

[31]. Holmgren KM, Berntsson T, Andersson E, Rydberg T, System aspects of biomass gasification with methanol synthesis - process concepts and energy analysis. Energy. 45(1):817-28 (2012).

[32]. Hu J, Wang Y, Cao C, Elliott DC, Stevens DJ, White JF, Conversion of biomass syngas to DME using a microchannel reactor. Ind Eng Chem Res. 44(6):1722-7 (2005).

[33]. Semelsberger TA, Borup RL, Greene HL, Dimethyl ether (DME) as an alternative fuel. J Power Sources. 156(2):497-511 (2006).

[34]. Zhang X, Solli C, Hertwich EG, Tian X, Zhang S, Exergy analysis of the process for dimethyl ether production through biomass steam gasification. Ind Eng Chem Res. 48(24):10976-85 (2009).

[35]. Clausen LR, Elmegaard B, Houbak N, Technoeconomic analysis of a low CO2 emission dimethyl ether (DME) plant based on gasification of torrefied biomass. Energy. 35(12):4831-42 (2010).

[36]. Tock L, Gassner M, Maréchal F, Thermochemical production of liquid fuels from biomass: Thermoeconomic modeling, process design and process integration analysis. Biomass Bioenerg. 34(12):183854 (2010).

[37]. Simbeck D, Chang E, Hydrogen Supply: Cost Estimate for Hydrogen Pathways - Scoping Analysis. SFA Pacific, Inc. Mountain View, California. NREL/SR-540-32525. Golden, CO (2002).

[38]. Tock L, Maréchal F, Co-production of hydrogen and electricity from lignocellulosic biomass: Process design and thermo-economic optimization. Energy. 45(1):339-49 (2012).

[39]. Gassner M, Maréchal F, Thermo-economic process model for thermochemical production of synthetic 
natural gas (SNG) from lignocellulosic biomass. Biomass Bioenerg. 33(11):1587-604 (2009).

[40]. Juraík M, Sues A, Ptasinski KJ, Exergetic evaluation and improvement of biomass-to-synthetic natural gas conversion. Energy Environ Sci. 2(7):791-801 (2009).

[41]. Heyne S, Harvey S, Methane from biomass: Process-integration aspects. Proceedings of Institution of Civil Engineers: Energy. 162(1):13-22 (2009).

[42]. van der Meijden CM, Veringa HJ, Rabou LPLM, The production of synthetic natural gas (SNG): A comparison of three wood gasification systems for energy balance and overall efficiency. Biomass Bioenerg. 34(3):302-11 (2010).

[43]. Gassner M, Maréchal F, Thermo-economic optimisation of the polygeneration of synthetic natural gas (SNG), power and heat from lignocellulosic biomass by gasification and methanation. Energy Environ Sci. 5(2):5768-89 (2012).

[44]. Haro P, Ollero P, Villanueva Perales AL, Gómez-Barea A, Thermochemical biorefinery based on dimethyl ether as intermediate: Technoeconomic assessment. Appl Energy. 102:950-61 (2013).

[45]. Cherubini F, Jungmeier G, Wellisch M, Willke T, Skiadas I, van Ree R, et al. Toward a common classification approach for biorefinery systems. Biofuel Bioprod Bioref. 3(5):534-46 (2009).

[46]. van Ree R, Annevelink B, Status Report Biorefinery 2007. Report 847, SenterNovem, Wageningen, The Netherlands

http://www.biorefinery.nl/fileadmin/biorefinery/docs/publications/StatusDocumentBiorefinery2007final211 107.pdf [accessed October 2012]

[47]. Bridgwater AV, Renewable fuels and chemicals by thermal processing of biomass. Chem Eng J. 91(23):87-102 (2003).

[48]. Prins MJ, Ptasinski KJ, Janssen FJJG, More efficient biomass gasification via torrefaction. Energy. 31(15):3458-70 (2006).

[49]. Demirbaş A, Biomass resource facilities and biomass conversion processing for fuels and chemicals. Energy Conv Manag. 42(11):1357-78 (2001).

[50]. Goyal HB, Seal D, Saxena RC, Bio-fuels from thermochemical conversion of renewable resources: A review. Renew Sust Energ Rev. 12(2):504-17 (2008).

[51]. Higman C, van der Burgt M, Gasification. Elsevier Science (2003).

[52]. Haro P, Ollero P, Villanueva Perales AL, Reyes Valle C, Technoeconomic assessment of lignocellulosic ethanol production via DME (dimethyl ether) hydrocarbonylation. Energy. 44(1):891-901 (2012).

[53]. Wender I, Reactions of synthesis gas. Fuel Process Technol. 48(3):189-297 (1996).

[54]. Bartholomew CH, Farrauto RJ, Fundamentals of Industrial Catalytic Processes. $2^{\text {nd }}$ Edition. Wiley (2005).

[55]. Spath PL, Dayton DC, Preliminary screening - technical and economic assessment of synthesis gas to fuels and chemicals with emphasis on the potential for biomass-derived syngas. Report NREL/TP-51034929. Golden, CO, USA:NREL (2003).

[56]. Tijm PJA, Walker FJ, Brown DM, Methanol technology developments for the new millennium. Appl Catal A-Gen. 221:275-82 (2001).

[57]. Aasberg-Petersen K, Nielsen CS, Dybkjær I, Perregaard J, Large Scale Methanol Production from Natural

Gas. http://www.topsoe.com/business_areas/methanol/ /media/PDF\%20files/Methanol/Topsoe_large_scale_ methanol_prod_paper.ashx [accessed October 2012]

[58]. Lurgi Megamethanol, Lurgi's Brochure. http://lurgi.com/website/fileadmin/user_upload/1_PDF/1_Broshures_Flyer/englisch/0312e_MegaMethano I.pdf [accessed September 2012]

[59]. Matsumoto H, Nagai $\mathrm{H}$, Watanabe $\mathrm{H}$, Morita K, Makihara H, Advanced Technology for Large Scale Methanol Plant. Mitsubishi Heavy Industries Technical Review. 34(2):58-62 (1997).

[60]. Advanced Casale Technologies. Casale's Brochure. http://www.casale.ch/group/images/stories/Casale_Group/Downloads/Documents/advanced_casale_tec 
hnologies_june_2010.pdf [accessed September 2012]

[61]. Olofsson I, Nordin A, Söderlind U, Initial Review and Evaluation of Process Technologies and Systems Suitable for Cost-Efficient Medium-Scale Gasification for Biomass to Liquid Fuels. Energy Technology \& Thermal Process Chemistry, University of Umeå, Sweden (2005).

[62]. Heydorn EC, Diamond BW, Lilly RD, Commercial-scale demonstration of the liquid phase methanol (LPMEOHTM) process. Final report (Volume 2: project performance and economics) for the period 16 October 1992- 30 June 2003; June 2003. Sponsored by the Department of energy (2003).

[63]. Xu M, Lunsford JH, Goodman DW, Bhattacharyya A, Synthesis of dimethyl ether (DME) from methanol over solid-acid catalysts. Appl Catal A-Gen. 149(2):289-301 (1997).

[64]. [64] Jun K-, Lee H-, Roh H-, Park S-, Catalytic dehydration of methanol to dimethyl ether (DME) over solid-acid catalysts. Bulletin of the Korean Chemical Society. 23(6):803-6 (2002).

[65]. Yaripour F, Baghaei F, Schmidt I, Perregaard J, Catalytic dehydration of methanol to dimethyl ether (DME) over solid-acid catalysts. Catal Commun. 6(2):147-52 (2005).

[66]. Mii T, Uchida M, Fuel DME plant in East Asia. In: Proceedings of $15^{\text {th }}$ Saudi-Japan joint symposium Dhahran, Saudi Arabia. Toyo Engineering Corporation (TEC); November 27-28 (2005).

[67]. Brown DM, Bhatt BL, Hsiung TH, Lewnard JJ, Waller FJ, Novel technology for the synthesis of dimethyl ether from syngas. Catal Today. 8(3):279-304 (1991).

[68]. Stiefel M, Ahmad R, Arnold U, Döring M, Direct synthesis of dimethyl ether from carbon-monoxide-rich synthesis gas: Influence of dehydration catalysts and operating conditions. Fuel Process Technol. 92(8):1466-74 (2011)

[69]. García-Trenco A, Martínez A, Direct synthesis of DME from syngas on hybrid CuZnAl/ZSM-5 catalysts: New insights into the role of zeolite acidity. Appl Catal A-Gen. 411-412:170-9 (2012).

[70]. Shikada et al. Method for Producing Dimethyl Ether. US Patent Application 2006/0052647 A1 (2006).

[71]. Wender I, Friedel RA, Orchin M, Ethanol from methanol. Science. 113(2930):206-7 (1951).

[72]. Chen MJ, Feder HM, Rathke JW, A general homogeneous catalytic method for the homologation of methanol to ethanol. J Am Chem Soc. 104(25):7346-7 (1982).

[73]. Koermer GS, Slinkard WE, Methanol homologation reaction catalyzed by cobalt carbonyl. Ind Eng Chem Res. 17(3):231-6 (1978).

[74]. Watabane K, Kudo K, Sugita N, Kinetics and Mechanistic study of the methanol Homologation with Cobalt-Ruthenium mixed catalyst. N. Bull. Chem. Soc. Jpn. 58:2029-37 (1985).

[75]. Françoisse PB, Thyrion FC, Methanol to ethanol by homologation: Kinetic approach. Ind Eng Chem Res. 22(4):542-8 (1983).

[76]. Santacesaria E, Di Serio M, Gelosa D, Carrà S, Kinetics of methanol homologation. Part I. Behaviour of cobalt-phosphine-iodine catalysts. J Mol Catal A-Chem. 58(1):27-42 (1990).

[77]. Nowicki L, Ledakowicz S, Zarzycki R, Kinetics of rhodium-catalyzed methanol carbonylation. Ind Eng Chem Res. 31(11):2472-5 (1992).

[78]. Catalyst deactivation and regeneration. Kirk-Othmer Encyclopedia of Chemical Technology. doi: 10.1002/0471238961.1415021218150209.a01.pub2 (2003)

[79]. Maitlis PM, Haynes A, James BR, Catellani M, Chiusoli GP, lodide effects in transition metal catalyzed reactions. Dalton Transactions. (21):3409-19 (2004).

[80]. Klingler RJ, Chen MJ, Rathke JW, Kramarz KW, Effect of phosphines on the thermodynamics of the cobalt-catalyzed hydroformylation system. Organometallics. 26(2):352-7 (2007).

[81]. Gane RB, Process for the hydrocarbonylation of methanol to ethanol in the presence of added oxygencontaining compounds. US Patent 4,205,190 (1980).

[82]. Gane RB, Process for the production of ethanol and/or acetaldehyde by reacting methanol with synthesis gas. US Patent 4,262,154 (1981).

[83]. Gane RB, Process for the hydrocarbonylation of methanol to ethanol in the presence of an inert liquid. US Patent 4,319,056 (1982). 
[84]. Barclay JL, Hydrocarbonylation of methanol to ethanol in the presence of added compounds. US Patent 4,380,681 (1983).

[85]. Ishogai N, Process for producing ethanol. US Patent 4,423,258 (1983).

[86]. Halttunen ME, Niemelä MK, Krause AOI, Vuori Al, Liquid phase methanol hydrocarbonylation with homogeneous and heterogeneous Rh and Ru catalysts. J Mol Catal A-Chem. 109(3):209-17 (1996).

[87]. Halttunen ME, Niemelä MK, Krause AOI, Vuori Al, Some aspects on the losses of metal from the support in the hydrocarbonylation of methanol. J Mol Catal A-Chem. 144(2):307-14 (1999).

[88]. Walker E, Process for the selective homologation of methanol to ethanol. US Patent 4,227,634 (1981)

[89]. Wegman RW, Alcohol homologation. US Patent 4,720,200 (1988).

[90]. Chen MJ, Rathke JW, Homologation of methanol catalyzed by manganese carbonyl in tertiary aminemethanol solutions. Organometallics. 8(2):515-20 (1989).

[91]. Hargis D, Catalyst for converting methanol and synthesis gas to ethanol. US Patent 4,361,499 (1982).

[92]. Hargis D, Ethanol from methanol and synthesis gas. US Patent 4,370,507 (1983).

[93]. Rathke JW, Chen MJ, Klingler RJ, Gerald RE, Marshall CL, Rodgers JL, Selective catalytic ethanol synthesis. Proceedings of the 2006 Meeting of the DOE/BES Catalysis and Chemical Transformations Program. Cambridge, Maryland, May 21-24 (2006).

[94]. Ono H, Fujiwara K, Hashimoto M, Sugiyama E, Yoshida K, Promotion effect of mixed halides on homogeneous ruthenium catalysis in direct synthesis of ethanol from hydrogen and carbon monoxide. $\mathrm{J}$ Mol Catal A-Chem. 57(1):113-23 (1989).

[95]. Jenner G, Andrianary $P$, One and two-stage synthesis of ethanol by hydrocarbonylation of methanol in chelating solvents. J Catal. 88(2):535-7 (1984)

[96]. Braca G, Paladini L, Sbrana G, Valentini G, Andrich G, Gregorio G, Carbonylation and homologation of dimethyl ether in the presence of ruthenium catalysts. Ind Eng Chem Res. 20(1):115-22 (1981).

[97]. Rathke J, Chen M, Klingler B, Gerald R, Marshall C, Rodgers J, Selective Catalytic Ethanol Synthesis. Argonne National Research Laboratory [presentation]. [accessed September 2009]

[98]. Carbon monoxide. Kirk-Othmer Encyclopedia of Chemical Technology. doi: 10.1002/0471238961.0301180216090518.a02.pub2 (2001)

[99]. Jenner G, The selectivity problem in the homogeneous carbonylation and hydrocarbonylation of alcohols and esters. Appl. Catal. 50(1):99-118 (1989).

[100]. Moloy KG, Wegman RW, Rhodium-catalyzed reductive carbonylation of methanol. Organometallics. 8(12):2883-92 (1989).

[101]. Juran B, Porcelli RV Convert methanol to ethanol. Hydrocarbon Process Int Ed. 64(10):85-7 (1985).

[102]. Ethanol. Ullmann's Encyclopedia of Industrial Chemistry. doi: 10.1002/14356007.a09 587 (2002)

[103]. Rachmady W, Vannice MA, Acetic acid hydrogenation over supported platinum catalysts. J Catal. 192(2):322-34 (2000).

[104]. Howard MJ, Jones MD, Roberts MS, Taylor SA, C1 to acetyls: Catalysis and process. Catal Today. 18(4):325-54 (1993).

[105]. Howard MJ, Sunley GJ, Poole AD, Watt RJ, Sharma BK, New acetyls technologies from BP chemicals. In: Hideshi Hattori and Kiyoshi Otsuka, Editor(s), Studies in Surface Science and Catalysis, Elsevier, Volume 121, Pages 61-68 (1999).

[106]. BP documentation. Passing the acid test. Frontiers. December (2008). http://www.bp.com/liveassets/bp_internet/globalbp/STAGING/global_assets/downloads/B/bpf23_30-

33_cativa.pdf [accessed June 2010]

[107]. Winter CL, Make ethanol via syngas. Hydrocarbon Process. 65(4):71-3 (1986).

[108]. Schuster L, Continuous preparation of ethanol. US Patent 4,517,391 (1985).

[109]. Rachmady W, Vannice MA, Acetic acid reduction by $\mathrm{H} 2$ on bimetallic Pt-Fe catalysts. J Catal. 209(1):87-98 (2002).

[110]. Rachmady W, Vannice MA, Acetic acid reduction by $\mathrm{H}_{2}$ over supported pt catalysts: A DRIFTS and 
TPD/TPR study. J Catal. 207(2):317-30 (2002).

[111]. Pallassana $V$, Neurock $M$, Reaction paths in the hydrogenolysis of acetic acid to ethanol over pd(111), re(0001), and PdRe alloys. J Catal. 209(2):289-305 (2002).

[112]. Cressely J, Farkhani D, Deluzarche A, Kiennemann A, Evolution des especes carboxylates dans le cadre des syntheses $\mathrm{CO}-\mathrm{H} 2$. reduction de l'acide acetique sur systeme $\mathrm{Co}, \mathrm{Cu}$, Fe. Mater Chem Phys. 11(5):413-31 (1984).

[113]. Kitson et al. Catalyzed hydrogenation of carboxylic acids and their anhydrides to alcohols and/or ester. US Patent 4,985,572 (1991).

[114]. Stites RC, Methods and apparatus for selectively producing ethanol from synthesis gas. PCT International Application WO/2010 068318 A1 (2010).

[115]. Johnston VJ, Process for making ethanol from acetic acid. US Patent Application 2010/0197985 A1 (2010).

[116]. BASF. Make the right move with NanoSelect ${ }^{\mathrm{TM}}$ Catalysts. http://www.basf.de/basf2/img/pharma/2009-01/BASF_NanoSelect.pdf [accessed June 2010]

[117]. Zhu Y, Jones SB, Techno-economic Analysis for the Thermochemical Conversion of Lignocellulosic Biomass to Ethanol via Acetic Acid Synthesis. Pacific Northwest National Laboratory. Report PNNL18483. April (2009).

[118]. Jetvic et al. Process to make ethanol from acetic acid using acidic catalyst. US Patent Application 2011/0082322 A1 (2011).

[119]. Bradley MW. Process for the production of ethanol. PCT International Application WO/1983 03409 (1983).

[120]. www.enerkem.com [accessed May 2012]

[121]. Kapoor MP, Matsumura Y, Liquid-phase methanol carbonylation catalyzed over tin promoted nickelaluminium layered double hydroxide. Catal Today. 93-95:287-91 (2004).

[122]. Kummer et al. Continuous production of ethanol and plural stage distillation of the same. US Patent 4,454,358 (1984).

[123]. Merenov AS, Abraham MA, Catalyzing the carbonylation of methanol using a heterogeneous vapor phase catalyst. Catal Today. 40(4):397-404 (1998).

[124]. Nefedov BK, Shutkina EM, éidus YT, Rh-NaX as a heterogeneous catalyst for the synthesis of methyl acetate by the carbonylation of methanol with carbon monoxide at atmospheric pressure. Bulletin of the Academy of Sciences of the USSR Division of Chemical Science. 24(3):657-8 (1975).

[125]. Nefedov BK, Sergeeva NS, Zueva TV, Shutkina EM, Eidus YT, Carbonylation reactions communication 22. Synthesis of methyl acetate by carbonylation of methanol with carbon monoxide in presence of Rh-zeolite NaX catalyst at atmospheric pressure. Bulletin of the Academy of Sciences of the USSR Division of Chemical Science. 25(3):565-9 (1976).

[126]. Chornet E, Production of ethanol from methanol. US Patent Application 2009/0221725 A1 (2009).

[127]. Marie-Rose SC, Chornet E, Lynch D, Lavoie J-, From biomass-rich residues into fuels and green chemicals via gasification and catalytic synthesis. WIT Transactions on Ecology and the Environment. 143:123-32 (2011).

[128]. Cheung et al. Process for carbonylation of alkyl ethers. US Patent 7,465,822 B2 (2008).

[129]. Smith, Process for preparing carboxylic acids and derivatives thereof. US Patent 7,642,372 B2 (2010).

[130]. Smith, Process for preparing carboxylic acids. US Patent 5,420,345 (1995).

[131]. Cheung P, Bhan A, Sunley GJ, Law DJ, Iglesia E, Site requirements and elementary steps in dimethyl ether carbonylation catalyzed by acidic zeolites. J Catal. 245(1):110-23 (2007).

[132]. Liu J, Xue H, Huang X, Wu P-, Huang S-, Liu S-, et al. Stability enhancement of H-mordenite in dimethyl ether carbonylation to methyl acetate by pre-adsorption of pyridine. Cuihua Xuebao/Chinese J Catalysis. 31(7):729-38 (2010). 
[133]. Boronat M, Martínez C, Corma A, Mechanistic differences between methanol and dimethyl ether carbonylation in side pockets and large channels of mordenite. Phys Chem Chem Phys. 13(7):2603-12 (2011).

[134]. Uhm SJ, Process for the preparation of ethanol from methanol. US Patent 5,414,161 (1995).

[135]. Bessling B, Löning J-, Ohligschläger A, Schembecker G, Sundmacher K, Investigations on the synthesis of methyl acetate in a heterogeneous reactive distillation process. Chem Eng Technol. 21(5):393-400 (1998).

[136]. Zoeller JR, Eastman chemical company's "chemicals from coal" program: The first quarter century. Catal Today. 140(3-4):118-26 (2009).

[137]. Agreda $\mathrm{VH}$, Reactive distillation process for the production of methyl acetate. US Patent 4,435,595 (1984).

[138]. Huss RS, Chen F, Malone MF, Doherty MF, Reactive distillation for methyl acetate production. Comput Chem Eng. 27(12):1855-66 (2003).

[139]. Esterification. Kirk-Othmer Encyclopedia of Chemical Technology. doi: 10.1002/0471238961.0519200501191201.a01 (2000)

[140]. Ethanol. Kirk-Othmer Encyclopedia of Chemical Technology. doi: 10.1002/0471238961.0520080112150719.a01.pub2 (2004)

[141]. Blanchard LA, Brennecke JF, Esterification of acetic acid with ethanol in carbon dioxide. Green Chem. 3(1):17-9 (2001).

[142]. Wyczesany A, Modeling of simultaneous chemical and phase equilibria in esterification of acetic acid with ethanol in high-pressure carbon dioxide. Ind Eng Chem Res. 46(16):5437-45 (2007).

[143]. Zhang B, Lin L, Zhuang J, Liu Y, Peng L, Jiang L, Hydrogenation of ethyl acetate to ethanol over nibased catalysts obtained from Ni/Al hydrotalcite-like compounds. Molecules. 15(8):5139-52 (2010).

[144]. van Beijnum et al. Hydrogenolysis reaction and catalyst suitable therefor. US Patent 5,198,592 (1993).

[145]. Ryashentseva MA, Avaev VI, Hydrogenation of ethyl acetate over supported rhenium catalysts. Russian Chemical Bulletin. 48(5):998-1000 (1999).

[146]. Wehner PS, Gustafson BL, Catalytic hydrogenation of esters over Pd/ZnO. J Catal. 135(2):420-6 (1992).

[147]. Bournonville et al. Process for producing alcohols by hydrogenolysis of carboxylic acid esters in the presence of a catalyst containing nickel and tin, germanium or lead. US Patent 4,628,130 (1986).

[148]. Travers et al. Catalytic process for manufacturing alcohols by hydrogenolysis of carboxylic acid esters. US Patent 4,456,775 (1984).

[149]. San X, Zhang $Y$, Shen W, Tsubaki N, New synthesis method of ethanol from dimethyl ether with a synergic effect between the zeolite catalyst and metallic catalyst. Energy and Fuels. 23(5):2843-4 (2009).

[150]. Zhang $Y$, San X, Tsubaki N, Tan $Y$, Chen J, Novel ethanol synthesis method via C1 chemicals without any agriculture feedstocks. Ind Eng Chem Res. 49(11):5485-8 (2010).

[151]. Li X, San X, Zhang Y, Ichii T, Meng M, Tan Y, et al. Direct synthesis of ethanol from dimethyl ether and syngas over combined H-mordenite and Cu/ZnO catalysts. ChemSusChem. 3(10):1192-9 (2010).

[152]. Cheung $P$, Bhan A, Sunley GJ, Iglesia E, Selective carbonylation of dimethyl ether to methyl acetate catalyzed by acidic zeolites. Angewandte Chemie - International Edition. 45(10):1617-20 (2006).

[153]. Acetic Acid. Ullmann's Encyclopedia of Industrial Chemistry. doi: 10.1002/14356007.a01_045

[154]. Solvents. Ullmann's Encyclopedia of Industrial Chemistry. doi: 10.1002/14356007.a24_437

[155]. Cellulose Esters, Organic Esters. Kirk-Othmer Encyclopedia of Chemical Technology. doi: 10.1002/0471238961.1518070107050415.a01

[156]. Bhan A, Allian AD, Sunley GJ, Law DJ, Iglesia E, Specificity of sites within eight-membered ring zeolite channels for carbonylation of methyls to acetyls. J Am Chem Soc. 129(16):4919-24 (2007). 
[157]. Liu J, Xue H, Huang X, Li Y, Shen W, Dimethyl ether carbonylation to methyl acetate over HZSM35. Catal Lett. 139(1-2):33-7 (2010).

[158]. Boronat M, Martínez-Sánchez C, Law D, Corma A, Enzyme-like specificity in zeolites: A unique site position in mordenite for selective carbonylation of methanol and dimethyl ether with CO. J Am Chem Soc. 130(48):16316-23 (2008).

[159]. Yang G, San X, Jiang N, Tanaka Y, Li X, Jin Q et al. A new method of ethanol synthesis from dimethyl ether and syngas in a sequential dual bed reactor with the modified zeolite and $\mathrm{Cu} / \mathrm{ZnO}$ catalysts. Catal Today. 164(1):425-8 (2011).

[160]. Ehrler JL, Juran B, VAM and $\mathrm{Ac}_{2} \mathrm{O}$ by carbonylation. Hydrocarbon Process Int Ed. 61(12):109-13 (1982).

[161]. Acetic Anhydride and Mixed Fatty Acid Anhydrides. Ullmann's Encyclopedia of Industrial Chemistry. doi: 10.1002/14356007.a01_065

[162]. Zoeller JR, Agreda VH, Cook SL, Lafferty NL, Polichnowski SW, Pond DM, Eastman chemical company acetic anhydride process. Catal Today. 13(1):73-91 (1992).

[163]. Wan C-G, Process for the preparation of ethanol from methanol, carbon monoxide and hydrogen. US Patent 4,497,967 (1984).

[164]. Keil FJ, Methanol-to-hydrocarbons: Process technology. Microporous and Mesoporous Materials. 29(1-2):49-66 (1999).

[165]. Fuels, Synthetic, Liquid Fuels. Kirk-Othmer Encyclopedia of Chemical Technology. doi: 10.1002/0471238961.12091721080114.a01

[166]. Olsbye U, Svelle S, Bjrgen M, Beato P, Janssens TVW, Joensen F et al. Conversion of methanol to hydrocarbons: How zeolite cavity and pore size controls product selectivity. Angewandte Chemie International Edition. 51(24):5810-31 (2012).

[167]. Chang CD, Silvestri AJ. The conversion of methanol and other O-compounds to hydrocarbons over zeolite catalysts. J Catal. 47(2):249-59 (1977).

[168]. Mokrani T, Scurrell M, Gas conversion to liquid fuels and chemicals: The methanol route-catalysis and processes development. Catalysis Reviews - Science and Engineering. 51(1):1-145 (2009).

[169]. Kvisle S, Fuglerud T, Kolboe S, Olsbye U, Lillerud KP, Vora BV, Methanol-to-Hydrocarbons. Handbook of Heterogeneous Catalysis. Wiley-VCH Verlag GmbH \& Co. KGaA (2008).

[170]. Jones SB, Zhu Y, Techno-economic Analysis for the Conversion of Lignocellulosic Biomass to Gasoline via the Methanol-to-Gasoline (MTG) Process. Richland, WA: Pacific Northwest National Laboratory (PNNL); Report No.: PNNL-18481 (2009).

[171]. Tabak SA, Yurchak S, Conversion of methanol over ZSM-5 to fuels and chemicals. Catal Today. 6(3):307-27 (1990).

[172]. Haro P, Trippe F, Stahl R, Henrich E, Bio-syngas to gasoline and olefins via DME - A comprehensive techno-economic assessment. Appl Energy. 108:54-65 (2013).

[173]. Zhu Y, Jones SB, Biddy MJ, Dagle RA, Palo DR, Single-step syngas-to-distillates (S2D) process based on biomass-derived syngas - A techno-economic analysis. Bioresour Technol. 117:341-51 (2012).

[174]. Haro P, Reyes Valle C, Villanueva Perales AL, Ollero P, Caraballo J. García Redondo JA et al. Techno-Economic Assessment of Production of Olefins via Thermochemical Conversion of Biomass (BioMTO process). Proceedings of the $19^{\text {th }}$ European Biomass Conference. Berlin, 6-10 June 2011, Pages 1113-6 (2011).

[175]. Avidan AA, Gasoline and Distillate Fuels From Methanol. In: Bibby DM, editor. Studies in Surface Science and Catalysis. Methane Conversion. Proceedings of a Symposium on the Production of Fuels and Chemicals from Natural Gas. Volume 36 ed. Elsevier; p. 307-23 (1988).

[176]. Ethylene. Ullmann's Encyclopedia of Industrial Chemistry. doi: 10.1002/14356007.a10_045.pub3

[177]. Thinnes B, Bio-based polymers could be next big thing. Hydrocarbon Process. 91(2) (2012).

[178]. Ethylene from Ethanol. Chematur Brochure. 
http://www.chematur.se/sok/download/Ethylene_rev_0904.pdf [accessed February 2012]

[179]. Tret'yakov VF, Makarfi YI, Tret'yakov KV, Frantsuzova NA, Talyshinskii RM, The catalytic conversion of bioethanol to hydrocarbon fuel: A review and study. Catalysis in Industry. 2(4):402-20 (2010).

[180]. Chen Y, Wu Y, Tao L, Dai B, Yang M, Chen Z, et al. Dehydration reaction of bio-ethanol to ethylene over modified SAPO catalysts. J Ind Eng Chem. 16(5):717-22 (2010).

[181]. Phillips CB, Datta R, Production of ethylene from hydrous ethanol on H-ZSM-5 under mild conditions. Ind Eng Chem Res. 36(11):4466-75 (1997).

[182]. Takahara I, Saito M, Inaba M, Murata K, Dehydration of ethanol into ethylene over solid acid catalysts. Catal Lett. 105(3-4):249-52 (2005).

[183]. Hu Y, Zhan N, Dou C, Huang H, Han Y, Yu D, et al. Selective dehydration of bio-ethanol to ethylene catalyzed by lanthanum-phosphorous-modified HZSM-5: Influence of the fusel. Biotechnology Journal. 5(11):1186-91 (2010).

[184]. Bedia J, Barrionuevo R, Rodríguez-Mirasol J, Cordero T, Ethanol dehydration to ethylene on acid carbon catalysts. Appl Catal B-Environ. 103(3-4):302-10 (2011).

[185]. Le Van Mao R, Nguyen TM, McLaughlin GP, The bioethanol-to-ethylene (B.E.T.E.) process. Appl Catal. 48(2):265-77 (1989).

[186]. Morschbacker A, Bio-ethanol based ethylene. Polym. Rev. 49(2):79-84 (2009).

[187]. Haro P, Trippe F, Ollero P, Stahl R, Ethylene from biomass: A comparison between bioethanol dehydration and other thermochemical processes. Unpublished results.

[188]. Green Propylene. Chem System PERP Program, NEXANT. Report Abstract, PERP07/08S11. April (2009). http://www.chemsystems.com/reports/search/docs/abstracts/0708S11_abs.pdf

[189]. Huang S, Liu S, Xin W, Bai J, Xie S, Wang Q, et al. Metathesis of ethene and 2-butene to propene on WIAI $2 \mathrm{O} 3-\mathrm{HY}$ catalysts with different HY contents. J Mol Catal A-Chem. 226(1):61-8 (2005).

[190]. Mol JC, Industrial applications of olefin metathesis. J Mol Catal A-Chem. 213(1):39-45 (2004).

[191]. Biobutanol: The Next Big Biofuel. Chem Systems NEXANT, Topical Report. February (2008).

[192]. Ndou AS, Plint N, Coville NJ, Dimerisation of ethanol to butanol over solid-base catalysts. Appl Catal A-Gen. 251(2):337-45 (2003).

[193]. Tsuchida $T$, Sakuma S, Takeguchi $T$, Ueda W, Direct synthesis of $n$-butanol from ethanol over nonstoichiometric hydroxyapatite. Ind Eng Chem Res. 45(25):8634-42 (2006).

[194]. Ogo S, Onda A, Yanagisawa K, Selective synthesis of 1-butanol from ethanol over strontium phosphate hydroxyapatite catalysts. Appl Catal A-Gen. 402(1-2):188-95 (2011).

[195]. Marcu I-, Tichit D, Fajula F, Tanchoux N, Catalytic valorization of bioethanol over Cu-Mg-Al mixed oxide catalysts. Catal Today. 147(3-4):231-8 (2009).

[196]. León M, Díaz E, Ordóñez S, Ethanol catalytic condensation over mg-al mixed oxides derived from hydrotalcites. Catal Today. 164(1):436-42 (2011).

[197]. Carvalho DL, De Avillez RR, Rodrigues MT, Borges LEP, Appel LG, Mg and Al mixed oxides and the synthesis of n-butanol from ethanol. Appl Catal A-Gen. 415-416:96-100 (2012).

[198]. Tsodikov MV, Yandieva FA, Kugel VY, Chistyakov AV, Gekhman AE, Moiseev II, Reductive dehydration of ethanol: A new route towards alkanes. Catal Lett. 121(3-4):199-208 (2008).

[199]. Dahlbom S, Landgren H, Fransson P, Alternatives for Bio-Butanol Production. Lund University. http://www.chemeng.Ith.se/ket050/Finalreport2011/Statoil.pdf [accessed September 2012]

[200]. Mascal M, Chemicals from biobutanol: Technologies and markets. Biofuel Bioprod Bioref. 6(4):48393 (2012).

[201]. Wright ME, Harvey BG, Quintana RL, Highly efficient zirconium-catalyzed batch conversion on 1butene: A new route to jet fuels. Energy and Fuels. 22(5):3299-302 (2008).

[202]. Wass DF, Dowson GRM, Conversion of Alcohols. International Patent Application, WO 2012/004572 A1 (2012). 
[203]. Inui K, Kurabayashi T, Sato S, Direct synthesis of ethyl acetate from ethanol over $\mathrm{Cu}-\mathrm{Zn}-\mathrm{Zr}-\mathrm{Al}-\mathrm{O}$ catalyst. Appl Catal A-Gen. 237(1-2):53-61 (2002).

[204]. Carotenuto G, Tesser R, Di Serio M, Santacesaria E, Kinetic study of ethanol dehydrogenation to ethyl acetate promoted by a copper/copper-chromite based catalyst. Catal Today. DOI: 10.1016/j.cattod.2012.02.054 (2012)

[205]. Santacesaria E, Carotenuto G, Tesser R, Di Serio M, Ethanol dehydrogenation to ethyl acetate by using copper and copper chromite catalysts. Chem Eng J. 179:209-20 (2012).

[206]. Colley SW, Fawcett CR, Rathmell C, Tuck MWM, Process. Kvaerner Process Technology Ltd., European Patent 0,990,638 (2000).

[207]. Hong Thuy NT, Kikuchi $Y$, Sugiyama H, Noda M, Hirao M, Techno-economic and environmental assessment of bioethanol-based chemical process: A case study on ethyl acetate. Environ Prog Sustain Energy. 30(4):675-84, (2011).

[208]. Inaba M, Murata K, Saito M, Takahara I, Ethanol conversion to aromatic hydrocarbons over several zeolite catalysts. Reaction Kinetics and Catal Lett. 88(1):135-41 (2006).

[209]. Barthos R, Széchenyi A, Solymosi F, Decomposition and aromatization of ethanol on ZSM-based catalysts. J Phys Chem B. 110(43):21816-25 (2006).

[210]. Inaba M, Murata K, Saito M, Takahara I, Production of olefins from ethanol by fe-supported zeolite catalysts. Green Chem. 9(6):638-46, (2007).

[211]. Gayubo AG, Alonso A, Valle B, Aguayo AT, Olazar M, Bilbao J, Hydrothermal stability of HZSM-5 catalysts modified with $\mathrm{Ni}$ for the transformation of bioethanol into hydrocarbons. Fuel. 89(11):3365-72 (2010).

[212]. Sun J, Zhu K, Gao F, Wang C, Liu J, Peden CHF, et al. Direct conversion of bio-ethanol to isobutene on nanosized $\mathrm{Zn}_{x} \mathrm{Zr}_{\mathrm{y}} \mathrm{O}_{z}$ mixed oxides with balanced acid - base sites. $\mathrm{J}$ Am Chem Soc. 133(29):11096-9 (2011).

[213]. Viswanadham N, Saxena SK, Kumar J, Sreenivasulu $P$, Nandan D, Catalytic performance of nano crystalline H-ZSM-5 in ethanol to gasoline (ETG) reaction. Fuel. 95:298-304 (2012).

[214]. Okazaki K, Kishida T, Ogawa K, Nozaki T, Direct conversion from methane to methanol for high efficiency energy system with exergy regeneration. Energy Conv Manag. 43(9-12):1459-68 (2002).

[215]. Indarto A, A review of direct methane conversion to methanol by dielectric barrier discharge. IEEE Trans Dielectr Electr Insul. 15(4):1038-43 (2008).

[216]. Chen L, Zhang X-, Huang L, Lei L-, Partial oxidation of methane with air for methanol production in a post-plasma catalytic system. Chem Eng Process: Process Intensification. 48(8):1333-40 (2009).

[217]. Reyes Valle C, Villanueva Perales AL, Ollero P, Gómez-Barea A, Techno-economic assessment of biomass-to-ethanol by indirect fluidized bed gasification: impact of reforming technologies and comparison with entrained flow gasification. Appl Energy. 109:254-266 (2013).

[218]. Coal Liquefaction - A research \& development needs assessment. Department of Energy USA. DOE/ER-0400 UC-108. Contract No: DE-AC01-87ER30110 (1989).

[219]. Baliban RC, Elia JA, Weekman V, Floudas CA, Process synthesis of hybrid coal, biomass, and natural gas to liquids via fischer-tropsch synthesis, ZSM- 5 catalytic conversion, methanol synthesis, methanol-to-gasoline, and methanol-to-olefins/distillate technologies. Comput Chem Eng. 47:29-56 (2012).

[220]. Baliban RC, Elia JA, Misener R, Floudas CA, Global optimization of a MINLP process synthesis model for thermochemical based conversion of hybrid coal, biomass, and natural gas to liquid fuels. Comput Chem Eng. 42:64-86 (2012).

[221]. Baliban RC, Elia JA, Floudas CA, Optimization framework for the simultaneous process synthesis, heat and power integration of a thermochemical hybrid biomass, coal, and natural gas facility. Comput Chem Eng. 35(9):1647-90 (2011)

[222]. Elia JA, Baliban RC, Xiao X, Floudas CA, Optimal energy supply network determination and life 
cycle analysis for hybrid coal, biomass, and natural gas to liquid (CBGTL) plants using carbon-based hydrogen production. Comput Chem Eng. 35(8):1399-430 (2011).

[223]. Baliban RC, Elia JA, Floudas CA, Toward novel hybrid biomass, coal, and natural gas processes for satisfying current transportation fuel demands, 1: Process alternatives, gasification modeling, process simulation, and economic analysis. Ind Eng Chem Res. 49(16):7343-70 (2010).

[224]. Elia JA, Baliban RC, Floudas CA, Toward novel hybrid biomass, coal, and natural gas processes for satisfying current transportation fuel demands, 2: Simultaneous heat and power integration. Ind Eng Chem Res. 49(16):7371-88 (2010). 